Portland State University

PDXScholar

Environmental Science and Management

Faculty Publications and Presentations

Environmental Science and Management

9-2018

\title{
Public Perceptions of Mountain Lake Fisheries Management in National Parks
}

Ariana M. Chiapella

Portland State University, ac23@pdx.edu

Max Nielsen-Pincus

Portland State University, maxnp@pdx.edu

Angela L. Strecker

Portland State University, angela.strecker@wwu.edu

Follow this and additional works at: https://pdxscholar.library.pdx.edu/esm_fac

Part of the Environmental Indicators and Impact Assessment Commons, Environmental Monitoring Commons, and the Natural Resources Management and Policy Commons

Let us know how access to this document benefits you.

\section{Citation Details}

Chiapella, Ariana M.; Nielsen-Pincus, Max; and Strecker, Angela L., "Public Perceptions of Mountain Lake Fisheries Management in National Parks" (2018). Environmental Science and Management Faculty Publications and Presentations. 243.

https://pdxscholar.library.pdx.edu/esm_fac/243

This Post-Print is brought to you for free and open access. It has been accepted for inclusion in Environmental Science and Management Faculty Publications and Presentations by an authorized administrator of PDXScholar. Please contact us if we can make this document more accessible: pdxscholar@pdx.edu. 


\title{
Public perceptions of mountain lake fisheries management in national parks
}

\author{
Chiapella, Ariana $\mathrm{M}^{\mathrm{ab}}$; Nielsen-Pincus, Max ${ }^{\mathrm{b}}$; Strecker, Angela $\mathrm{L}^{\mathrm{b}}$ \\ aCorresponding author: ac23@pdx.edu \\ bPortland State University, Department of Environmental Science and Management \\ P.O. Box 751, Portland, OR 97207 USA
}

\begin{abstract}
The legacy of fish stocking in mountain lake ecosystems has left behind a challenge for land managers around the globe. In the US and Canada, historically fishless mountain lakes have been stocked with trout for over a century. These non-native trout have cascading ecosystem effects, and can accumulate atmospherically deposited contaminants. While the negative impacts of stocking in these ecosystems have become increasingly apparent, wilderness fishing has garnered cultural value in the angling community. As a result, public lands managers are left with conflicting priorities. National park managers across the western US are actively trying to reconcile the cultural and ecological values of mountain lakes through the development of management plans for mountain lake fisheries. However, visitors' social perceptions, attitudes, and values regarding mountain lake fisheries management have remained unquantified, and thus largely left out of the decision-making process. Our study evaluated the recreation habits, values, and attitudes of national park visitors towards fish stocking and management of mountain lakes of two national parks in the Pacific Northwest. We found that most visitors favor fish removal using a conservation approach, whereby sensitive lakes are restored, while fish populations are maintained in lakes that are more resilient. An important consideration for managers is that many mountain lake anglers consume fish on an annual basis, thus we emphasize the use of outreach and education regarding the accumulation of contaminants in fish tissues. Our findings help elucidate the conflicting views of stakeholders, and we provide recommendations to inform management of mountain lakes fisheries in North America and abroad.
\end{abstract}

\section{Keywords}

Mountain lakes, fisheries management, national parks, fish stocking, contaminants, public perceptions

Declarations of interest: none. 


\section{Introduction}

Mountain lakes are perceived by many as pristine and untouched ecosystems. In reality, mountain waterbodies across the world have been under direct and indirect human influence for centuries, resulting in complex management challenges. Mountain lakes are typically oligotrophic waterbodies situated in high forest, subalpine, or alpine mountain ecosystems, with geologic barriers to upstream fish passage and hydrological dependence primarily on atmospheric precipitation and/or glaciers. In the American West, humans have introduced fish to mountain lakes since the turn of the $20^{\text {th }}$ century (Pister, 2001). State and federal fish and wildlife agencies originally began stocking trout into historically fishless mountain lakes to attract support for public lands conservation (Schoenfeld and Hendee, 1978). This practice continued for decades to maintain conservation support, and went largely unquestioned across management and academic communities until recently (Pister, 2001). Beginning in the latter half of the $20^{\text {th }}$ century, scientists began to discover the effects of fish in these lake ecosystems (e.g. Bradford et al., 1998; Eby et al., 2006; Finlay and Vredenburg, 2007; Knapp and Matthews, 2000).

The introduction of fish in mountain lakes has cascading ecological implications. Most notably, fish prey on aquatic invertebrates and amphibians, and outcompete amphibians and alpine-nesting birds for limited food resources, leading to declines in large-bodied zooplankton, macroinvertebrates, and amphibian species (Carlisle and Hawkins, 1998; Epanchin et al., 2010; Finlay and Vredenburg, 2007; Knapp and Matthews, 2000; Larson and Hoffman, 2002; Sarnelle and Knapp, 2004; Schindler and Parker, 2002). The stocking of non-native trout species in headwater lakes can also have negative downstream effects. In some systems, stocked fish can 
migrate downstream and compete with native trout species (Adams et al., 2001). In addition to these cascading ecosystem effects, fish stocked in mountain lakes can accumulate relatively high levels of atmospherically-deposited toxins - like polychlorinated biphenyls (PCBs), pesticides, and mercury - which can pose a threat to the health of local wildlife, as well as anglers who consume fish from these lakes (e.g. Landers et al., 2008; Moran et al., 2007).

While the effects of trout introductions on native ecosystems have become increasingly clear, the cultural importance of fish in mountain lakes has made management a complex issue. Many fish-stocked mountain lakes are located in federally protected wilderness areas, defined by the Wilderness Act of 1964 as "an area of undeveloped Federal land retaining its primeval character and influence, without permanent improvements ... which is protected and managed so as to preserve its natural conditions...", and many wilderness areas reside within national park boundaries. Vague policy language in the Wilderness Act has caused conflict and confusion around mountain lake fisheries management, because although the act calls for the preservation of natural and untrammeled land, it also upholds state jurisdiction with respect to fish and wildlife management (Landres et al., 2001). These conflicting passages have led to differences in interpretation of how to implement fisheries management practices in mountain lakes across US federal land management and regulatory agencies (e.g. US Forest Service, Bureau of Land Management, National Parks Service, and US Fish and Wildlife Service) (Landres et al., 2001). Trout stocking is still common in many mountain lakes managed by the US Forest Service and Bureau of Land Management, but the practice is at odds with National Park Service policies in the western US (Landres et al., 2001; Pister, 2001). At present, the National Parks 
Service has generally terminated mountain lake stocking programs in the western US (Landres et al., 2001).

Although stocking programs have largely ceased in US national parks, debate remains about how to best manage the remaining fisheries in mountain lake ecosystems. Individual national parks approach this problem differently. For example, Mount Rainier National Park (NP) has mainly used manual methods to remove fish (e.g. gill nets), and only experimentally from a few lakes, while other parks in the western US have used, or are considering, chemical removal techniques. North Cascades NP has used the plant-based piscicide rotenone, in conjunction with gill nets, to remove stocked fish from some mountain lakes. However, in 2016, the Washington Department of Fish and Wildlife began re-stocking select mountain lakes in North Cascades NP with species native to downstream waters. This management shift occurred after federal legislation supported by angling groups - the North Cascades National Park Service Complex Fish Stocking Act of 2014 - reinstated stocking in the park. In California's Sierra Nevada Mountains, fish eradication efforts have been kept confidential by management agencies, as to avoid gill net vandalism and re-stocking of lakes by anglers (Halverson, 2011).

The controversies that led to secretive fish removal efforts and the passing of the North Cascades Fish Stocking Act have illustrated the importance of managing mountain lakes as a socioecological system. The current mismatch in stakeholder priorities indicates that there is a conflict between the ecological and cultural value of mountain lakes, and while the opinions of some stakeholders are clear, the attitudes and perceptions of most park visitors toward the practice of fish stocking and management of fisheries are largely unknown. Watson et al. (2015) demonstrated that lack of public input is a common occurrence in wilderness management. 
However, there is substantial evidence that people can hold strong attitudes and beliefs that shape how they perceive wildlife management (e.g. Fulton et al., 1996; Hall et al., 2010; Manfredo, 2008). In national parks, visitor perspectives are important, as parks strive to maintain management practices that incorporate the needs and desires of visitors for their public lands, as per the National Parks Omnibus Management Act of 1998 (National Parks Service, 2006). In addition, addressing non-native species in mountain lakes is an important aspect of tourism management, which is an integral part of the public lands management (Hall et al. 2010). The importance of considering multidimensional socioecological complexity in land management is also illustrated by Papadimitriou (2012), who uses mathematical modeling approaches as a tool for addressing the complexity of land management. Clearly, there is a need to better assess public attitudes and values around mountain lake fisheries management. In addition, many anglers may not know that atmospherically deposited contaminants can accumulate in mountain lake fish. By understanding recreational habits of visitors and the distribution and drivers of their attitudes toward mountain lake fisheries, management agencies may be able to create plans that mitigate potential controversy and protect anglers from consuming potentially contaminated fish species.

\subsection{Research objectives}

The goals of our study were to determine: (1) visitors' attitudes toward a spectrum mountain lake fisheries management approaches; (2) how demographics, recreational habits, knowledge, and value-orientations around mountain lakes drive visitor attitudes towards fisheries management approaches; and (3) an approximation of the risk posed to visitors by 
consuming mountain lake fish, based on reported angling habits. Attitudes are defined as a negative or positive association toward an object (Ajzen 1991), and are driven by valueorientations, i.e., patterns of beliefs within specific domains (Manfredo et al. 2004, Whittaker et al. 2006). Assessing attitudes can be an important part of management decision making. Attitudes are considered components of a cognitive hierarchy that suggests values and attitudes can be used to anticipate human behavior, and are commonly used to understand human-wildlife interactions (Homer and Kahle, 1988; Fulton et al. 1996; Miller 2017). According to attitude theory, values are fundamental cognitions that represent ideal end states or desirable ways of behaving, and they form a foundation for attitudes, social norms, and beliefs, which in turn influence behavior (Fulton et al., 1996). Therefore, incorporating visitor attitudes into management plans could help mitigate against future public controversy around mountain lake fisheries management.

We hypothesize the following. First, visitor attitudes will align around two primary management approaches: one that favors maintaining fish in mountain lakes, and one that favors fish eradication. This is based on the theory that the primary wildlife value-orientations are either anthropocentric or biocentric in nature, with underlying drivers of dominance and mutualism, respectively (Manfredo, 2008; Vaske and Donnelly, 1999). In addition, we also expect to see a "middle" group emerge whose attitudes orient around both a concern for ecosystem health and a desire to maintain fisheries resources, as well as a group for whom the issue is not salient and therefore fails to assign an attitude in either direction. These four expected attitude groups can be explained by the finding from Teel and Manfredo (2010) that public lands visitors in the western US typically have attitudes driven by traditionalist 
(dominance-driven), mutualist (mutualism-driven), pluralist (both mutualism and dominance-

driven), and distanced (neither mutualism or dominance-driven) value-orientations. Second, based on the influence of demographics, value-orientations, recreation participation, and perceived ecosystem threats in determining support for wildlife management interventions, we expect these factors to be important predictors of management attitudes (Daigle et al., 2002; Jacobs et al., 2014; Larson et al., 2011; Manfredo, 2008; Scott and Willits, 1994; Teel et al., 2010). In line with Manfredo and Dayer's (2004) explanation of the continuum from "wildlife use" to "wildlife protection", we expect respondents in favor of stocking to participate in angling or be members of natural-resource groups, and indicate recreation as an important aspect of park waterbodies. Likewise, we expect those in favor of fish eradication to assign ecological importance to park waterbodies, be members of environmental groups, and list climate change as a threat to park ecosystems. Third, we expect the number of people who consume fish from these systems to be small, but those who do consume fish may do so frequently or have the perception that mountain lake fish are pristine.

\section{Materials and Methods}

In-person intercept surveys were conducted at campgrounds, trailheads, scenic overlooks, and trail crossings at North Cascades and Mount Rainer NP from July to August 2016. We selected these two parks because the National Parks Service was actively considering management options to balance the cultural value of mountain lake fisheries with the ecological value of fish removal (National Parks Service, 2007, 2017), providing the opportunity for this study to directly inform management decisions. National parks also generally have 
easily accessible trailheads, a diverse range of visitors, and higher visitation than, for instance, national forests (331 million versus 148 million visits in 2016, respectively; National Parks Service, 2017; U.S. Forest Service, 2016), making them appropriate places to study the diverse attitudes of those who visit public lands.

\subsection{Survey sites}

North Cascades NP is located along the northern US terminus of the Cascade Range in Washington State. Annual visitation at North Cascades NP is one of the lowest in the countryapproximately 23,000 (10-year average) (National Parks Service, 2017). There are approximately 40 lakes in the North Cascades NP Service Complex that contain fish populations (National Parks Service, 2007). Mount Rainier NP is located about two hours southeast of Seattle, Washington, and encompasses Mount Rainier. Annual visitation at Mount Rainier NP is about 1.2 million (10-year average) (National Parks Service, 2017). Approximately 35 of the park's lakes have reproducing fish populations (National Parks Service, 2017).

\subsection{Survey design}

Our study used in-person paper questionnaires to collect information on visitor attitudes towards fish stocking in mountain lakes and possible fisheries management approaches. Informed consent was obtained from all individual participants included in the study (Portland State University Institutional Review Board permit \#163799). Intercept surveys can be an effective means of gathering data on the habits, attitudes, values, and knowledge of a recreational study population, and are commonly used by federal land management agencies 
like the National Parks Service and US Forest Service (e.g., English et al., 2002; Taylor et al., 2011). In a given year, surveying visitors at trailheads, trail junctions, campgrounds, and other popular sites can provide representative information about a study population and can be a useful tool for informing management decisions. This method does include some bias, particularly against those who are not visiting the aforementioned sites, but may still have strong values with respect to public lands management.

Existing literature indicates that attitudes can be influenced by social norms, beliefs, and value-orientations; therefore we developed our survey to measure these attitude drivers. The questionnaire (Supplementary Material 1) included two parts. Part 1 collected demographic information about respondents, including postal code, age, gender, race/ethnicity, education, and income. Demographic information can help to understand the cultural context of a respondent, which may influence their value-orientations and attitudes via social norms - or the "expectations of how one... or others should behave" (Manfredo 2008, pp. 113). Part 2 was designed to further understand the social and cultural context of survey respondents by gathering information on respondents' recreational habits, knowledge, waterbody valueorientations, stocking attitudes, and fisheries management attitudes using Likert-scale questions (Likert, 1932; see Table 1). This section builds off literature showing that recreational behavior, knowledge and awareness of environmental issues, and beliefs around wildlife and the environment can influence attitudes and the nature of those attitudes (Borrie et al., 2002; Fulton et al., 1996; Hall et al., 2010; Larson et al., 2011; Teel and Manfredo, 2010; Whittaker et al., 2006). The survey was reviewed by National Parks Service staff, and was tested for clarity on a group of recreationalists prior to formal sampling. 
The survey asked respondents to rate their knowledge about park nature and management using a scale that ranged from no knowledge to very knowledgeable. Waterbody value-orientations were then assessed by determining how strongly respondents agreed or disagreed with the importance of national park waterbodies for given uses, e.g., for recreation, for preserving biodiversity. To assess environmental beliefs, we also asked respondents to indicate the extent to which they perceived different threats to national park ecosystems, e.g., climate change, pollution, introduced species. All Likert-type questions were measured on a 5point scale. Additional questions assessed whether respondents had prior knowledge of fish stocking practices, if they participate in angling on public lands, and if they have ever consumed fish from mountain lakes and if so, how often. Respondents also indicated if they were affiliated with any environmental, recreational, or natural resource-focused organizations, and if so, listed any groups they were affiliated with.

The survey asked respondents to rate several statements about the presence of introduced fish in mountain lakes to establish their initial perception of historical fish stocking. Subsequently, an informational excerpt was presented describing the history and current approaches to fish management in mountain lakes. After reading the excerpt, visitors were asked to rate their agreement or disagreement with a series of attitude statements regarding mountain lake fisheries management (Fig. 1).

Table 1 Sections from Part 2 of the survey, including the questions asked, list of rankings, and scale used.

\section{Question} Ranking Scale 


\begin{tabular}{|c|c|c|c|}
\hline $\begin{array}{l}\text { Activity } \\
\text { participation }\end{array}$ & $\begin{array}{l}\text { Overnight, day, hiking, site-seeing, } \\
\text { camping, backpacking, swimming, } \\
\text { fishing, picnicking, cycling, climbing }\end{array}$ & Yes/No & $\begin{array}{l}\text { Binary } \\
(0 \mid 1)\end{array}$ \\
\hline $\begin{array}{l}\text { Knowledge } \\
\text { ranking }\end{array}$ & $\begin{array}{l}\text { Mammals and birds, forests and } \\
\text { plants, streams and lakes, geology, } \\
\text { park management, aquatic animals, } \\
\text { glaciers, biodiversity, nutrient cycling }\end{array}$ & $\begin{array}{l}\text { Very little knowledge, } \\
\text { Limited knowledge, Average } \\
\text { knowledge, More than } \\
\text { average knowledge, Very } \\
\text { knowledgeable }\end{array}$ & $\begin{array}{l}\text { Likert } \\
(0-4)\end{array}$ \\
\hline $\begin{array}{l}\text { Waterbody } \\
\text { importance }\end{array}$ & $\begin{array}{l}\text { Recreation, clean water, biodiversity, } \\
\text { fishing, intrinsic, culture }\end{array}$ & $\begin{array}{l}\text { Strongly disagree, disagree, } \\
\text { neutral, agree, strongly agree }\end{array}$ & $\begin{array}{l}\text { Likert } \\
(-2-+2)\end{array}$ \\
\hline $\begin{array}{l}\text { Park ecosystem } \\
\text { health }\end{array}$ & & $\begin{array}{l}\text { Strongly disagree, disagree, } \\
\text { neutral, agree, strongly agree }\end{array}$ & $\begin{array}{l}\text { Likert } \\
(-2-+2)\end{array}$ \\
\hline $\begin{array}{l}\text { Ecosystem } \\
\text { threats }\end{array}$ & $\begin{array}{l}\text { Climate change, biodiversity loss, air } \\
\text { pollution, water pollution, visitor use, } \\
\text { non-native species, resource } \\
\text { extraction }\end{array}$ & $\begin{array}{l}\text { Not a threat, minor threat, } \\
\text { don't know, moderate threat, } \\
\text { major threat }\end{array}$ & $\begin{array}{l}\text { Likert } \\
(-2-+2)\end{array}$ \\
\hline $\begin{array}{l}\text { Urgency of } \\
\text { addressing } \\
\text { threats }\end{array}$ & $\begin{array}{l}\text { Climate change, biodiversity loss, air } \\
\text { pollution, water pollution, visitor use, } \\
\text { non-native species, resource } \\
\text { extraction }\end{array}$ & $\begin{array}{l}\text { No action needed, not very } \\
\text { urgent, neutral, somewhat } \\
\text { urgent, very urgent }\end{array}$ & $\begin{array}{l}\text { Likert } \\
(-2-+2)\end{array}$ \\
\hline $\begin{array}{l}\text { Stocking } \\
\text { knowledge }\end{array}$ & & Yes/No & $\begin{array}{l}\text { Binary } \\
(0 \mid 1)\end{array}$ \\
\hline $\begin{array}{l}\text { Initial stocking } \\
\text { attitude }\end{array}$ & $\begin{array}{l}\text { Important for recreation, adds value } \\
\text { to lakes, benefits other species, does } \\
\text { not have an ecological effect, has a } \\
\text { negative ecological effect }\end{array}$ & $\begin{array}{l}\text { Strongly disagree, disagree, } \\
\text { neutral, agree, strongly agree }\end{array}$ & $\begin{array}{l}\text { Likert } \\
(-2-+2)\end{array}$ \\
\hline $\begin{array}{l}\text { Group } \\
\text { membership }\end{array}$ & $\begin{array}{l}\text { Environmental, recreation, or resource } \\
\text { group }\end{array}$ & Self-report & Open \\
\hline $\begin{array}{l}\text { Angling } \\
\text { participation }\end{array}$ & & Yes/No & $\begin{array}{l}\text { Binary } \\
(0 \mid 1)\end{array}$ \\
\hline $\begin{array}{l}\text { Fish } \\
\text { consumption }\end{array}$ & $\begin{array}{l}\text { Annual consumption of mountain lake } \\
\text { fish }\end{array}$ & $\begin{array}{l}\text { Never, once, 1-5, 5-10, >10, } \\
\text { don't know }\end{array}$ & $0-10+$ \\
\hline
\end{tabular}

\subsection{Data collection}

Visitors were approached at popular trailheads and trail crossings, campgrounds, and central parking lots/scenic overlooks, in an effort to sample the diversity of visitor types at national parks ( $n=200$ at each park). Surveys were generally administered between 07:00 and 19:00 each day. Contact was attempted with all observed park users at each trailhead, parking 
lot, and campground to avoid survey bias, and because visitor mobility made stratified sampling techniques difficult. Prospective respondents were approached and asked if they were interested in taking a voluntary survey to document opinions about management issues in the park. Those who were over 18 years of age and who agreed to participate were given a clipboard with the survey, and allowed as long as they needed to complete (typically about 5-10 minutes). If groups were comprised of family members, one eligible group member was randomly selected to fill out the survey. Visitors were counted as non-respondents if they declined to take the survey or ignored or avoided contact with the surveyor when approached. Common reasons for non-response included time constraints of mountaineers and parents with young children, avoidance of surveyor, and limited English-speaking skills; it is possible that some of these groups would have had distinctive responses, but further surveying approaches were beyond the scope of this project.

\subsection{Data analyses}

The goal of our analyses was to identify common attitudes toward fish stocking and fisheries management in mountain lakes, as well as what influences these attitudes. We used exploratory factor analysis (EFA) for each group of questions to provide a rationale for averaging sets of variables into composite indices. EFA is appropriate because the questions on our survey were tailored to the specific issue of fish stocking and did not have a priori hypothesized relationships. Survey items that factored together were averaged to create indices that could represent important psychological constructs and serve as independent variables in regression models (i.e. existing knowledge of park nature, importance of park 
waterbodies, perceived ecosystem threats, initial stocking opinions). The same was done for the response variables for each model (i.e., management attitudes). In order to determine which constructs influenced respondents' management attitudes, we then used logistic regression to model how well our independent variables explained differences in fisheries management attitudes. All analyses were completed using R version 3.2.1 (R Core Team, 2016).

\subsubsection{Visitor attitudes toward fisheries management approaches}

To develop a cohesive set of attitude constructs, we created composite indices for different groups of attitude statements based on maximum likelihood EFA with varimax rotation. To ensure data met internal consistency requirements prior to EFA, we calculated Kaiser-Mayer-Olkin measures for each question set (cutoff 0.7 ). Then, a combination of factor eigenvalues (minimum of 1 ), variance explained (minimum of $5 \%$ ), parallel analysis, and scree plots were used to determine how many factors to include in each analysis (Supplementary Material 2). Items that loaded on a given factor above a threshold of 0.5 were grouped together. We confirmed item groupings using Cronbach's $\alpha$ (cutoff 0.6 , due to small number of items), assessing sum of squares for loadings of each factor, and by minimizing cross loadings (loading of one item $>0.5$ on one factor and $>0.3$ on one or more other factors) (Osbourne and Costello, 2009). Instead of using arbitrary factor scores as a value for each variable in our analyses, we instead averaged the Likert scale values of each item that exceeded the 0.5 factor score threshold for each group (DeAngelo and Nielsen-Pincus, 2017; Obeng and Aguilar, 2018).

\subsubsection{Drivers of visitor attitudes}


We used logistic regression models to determine which variables were associated with positive attitudes toward each management attitude group. Logistic regression was the most statistically robust option for our data, and allowed for easily interpretable results, since our goal was to determine attitude valence (agreement or disagreement with statements), as opposed to strength. Additionally, response variables were skewed (pro-stocking attitude was right-skewed, pro-preservation attitude was left-skewed), and composed of interval values, and were therefore better represented as binary, since this type of dataset violates certain assumptions of linear regression. We converted factor scores to a binary scale represented by 1 (agreed or strongly agreed with the group of statements) or 0 (disagreed with, strongly disagreed with, or was neutral toward the statements), for use in logistic regression (Brehm et al., 2004; DeAngelo and Nielsen-Pincus, 2017; Obeng and Aguilar, 2018). This approach allowed us to construct straightforward models that clearly indicated which independent variables were associated with a positive attitude toward each management attitude group. Final models were selected using Akaike Information Criteria (AIC), as well as by assessing model fit with McFadden's pseudo $R^{2}$. Analyses, model comparisons and outputs were completed using the $\mathrm{R}$ packages psych and nFactors for factor analysis (Raiche, 2010; Revelle, 2017), MASS for logistical model selection (Venables and Ripley, 2015), aod for model fitting (Lesnoff and Lancelot, 2012), and pscl for calculating pseudo $R^{2}$ values (Jackman, 2015)

\subsubsection{Visitor fish consumption}

We calculated the total percentage of visitors who report consuming mountain lake fish at each park. The total number of survey respondents who consume fish on at least one 
occasion per year was used to conduct a rough extrapolation to determine approximately how many visitors each year, on average, may be consuming fish from mountain lakes at each park. Extrapolations were based on the 10 -year averages of annual recreational visitation to each national park (National Parks Service, 2017).

\section{Results}

\subsection{Summary of responses}

A total of 400 responses - 200 from each park - were collected between July 21 and August 9, 2016. Of these, 395 responses were usable for analyses. Survey response rate was approximately $60 \%$ - with non-English speakers and visitors with young children representing the primary types of non-respondents. Respondents ranged in age from $18-78$, median income was $\$ 50,000-\$ 74,999$, most respondents were white/Caucasian, and most respondents held a Bachelor's degree at the time of the survey (Table 2).

Table 2 Demographic, group membership, stocking knowledge, and angling participation data for survey respondents $(\mathrm{N}=395)$, including total and percent of total respondents.

\begin{tabular}{lrr}
\hline Personal Income & $\mathbf{N}$ & $\%$ \\
$\$ 0-24,999$ & 59 & 15.0 \\
$\$ 25,000-49,999$ & 74 & 18.7 \\
$\$ 50,000-75,999$ & 72 & 18.2 \\
$\$ 75,000-99,999$ & 53 & 13.4 \\
$\$ 100,000-149,999$ & 47 & 11.9 \\
$\quad 3150,000+$ & 38 & 9.6 \\
$\quad$ No response & 52 & 13.2 \\
Education & & \\
$\quad$ High school & 20 & 5.1 \\
$\quad$ Some college & 80 & 20.3 \\
$\quad$ Bachelor's degree & 167 & 42.3
\end{tabular}




\begin{tabular}{lrr} 
Master's or law degree & 94 & 23.8 \\
Doctorate degree & 33 & 8.4 \\
No response & 1 & 0.2 \\
Gender & & \\
Male & 221 & 55.9 \\
Female & 171 & 43.3 \\
No response & 3 & 0.8 \\
Race/ethnicity & & \\
Asian/Pacific Islander & 16 & 4.1 \\
Black/African American & 4 & 1.0 \\
Hispanic & 8 & 2.0 \\
Native American & 6 & 2.0 \\
White/Caucasian & 348 & 88.1 \\
No response & 13 & 3.3 \\
Group membership & & \\
$\quad$ Environmental & 68 & 17.2 \\
Recreational & 50 & 12.7 \\
$\quad$ Resource & 4 & 1 \\
$\quad$ None & 273 & 69.1 \\
Prior stocking knowledge & 171 & 43.3 \\
Participation in angling on public lands & 115 & 29.1 \\
\hline
\end{tabular}

\subsection{Visitor attitudes toward fisheries management approaches}

After reading the given excerpt on fish stocking (Supplementary Material 1), most survey respondents (80\%) agreed that the ecological concerns of fish stocking were legitimate, and most agreed (54\%) that action should be taken - in the form of fish removal - to alleviate the effects of fish on mountain lake ecosystems (Fig. 1). A minority of respondents agreed that this issue is blown out of proportion, that fish add value to mountain lakes, and that stocking programs should be reinstated, despite ecological concerns (Fig. 1, Table 3). Over $40 \%$ of visitors thought that some lakes should be designated for fishing, while others should be designated for pristine nature, and worried that removing fish from too many lakes would then increase the negative effects of visitors on lakes that still had fish (Fig. 1). The attitude that fish would be best removed using only manual methods was also a popular one, with over $40 \%$ of 
respondents in agreement. In addition, many respondents (roughly 40\%) did not have an

opinion, or felt they did not know enough to comment (Fig. 1).

Not enough information to form an opinion

I don't have an opinion

Fish should be removed but only manually, not with chemicals

Removing fish may be just as harmful as leaving them in the lakes

Removing fish will increase visitor pressure on lakes that still have fish

Keep fish in some lakes, leave others pristine

Stocking programs should be reinstated

This issue is blown of out proportion

Fish add value, despite concerns

The benefits of fish outweigh the ecological consequences

Removing fish is an appropriate restoration approach

Action should be taken to alleviate the effects of fish on all mountain lakes

The concerns of fish stocking are legitimate
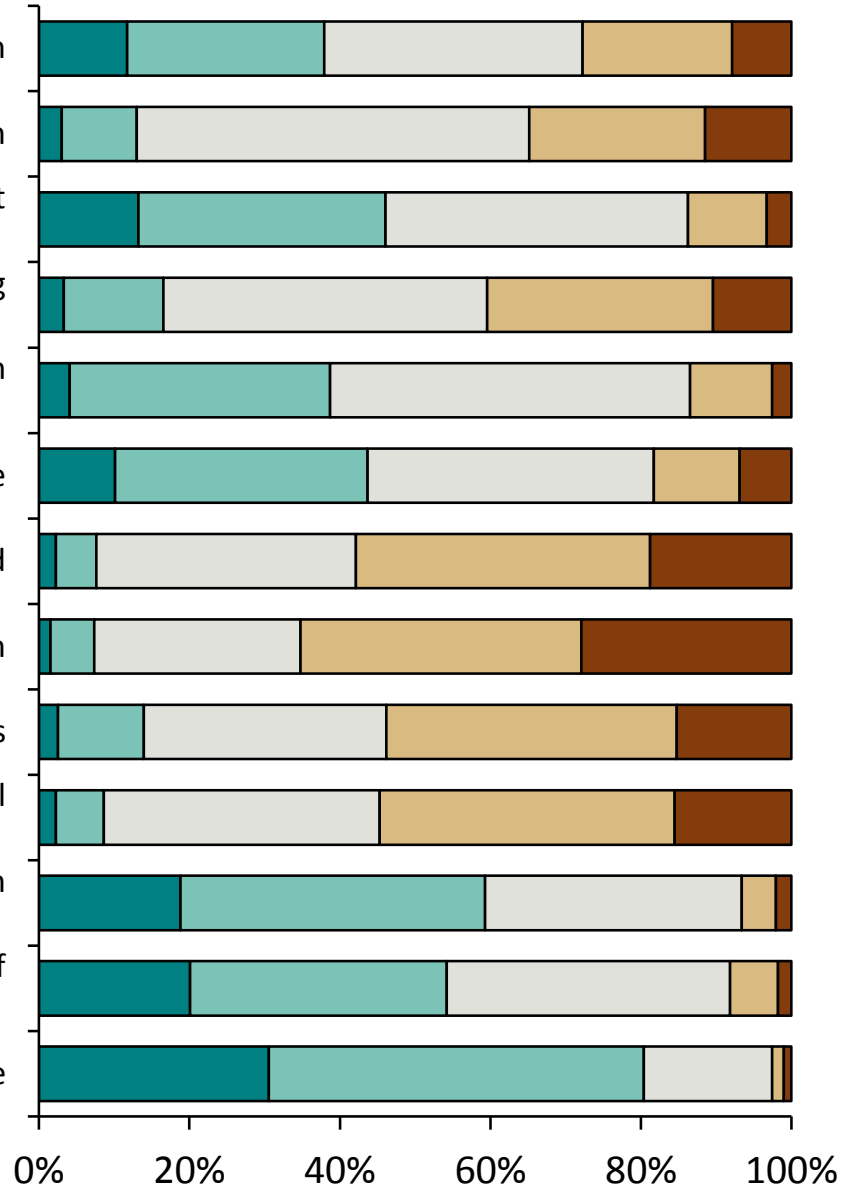

Strongly agree $\quad \square$ Agree $\quad \square$ Neutral $\quad \square$ Disagree $\quad \square$ Strongly disagree

Fig. 1 Survey responses for each mountain lake fish management statement.

Respondents indicated how strongly the agreed or disagreed (left to right) with each statement

The fisheries management attitude statements (Fig. 1) grouped into four attitude groups in our factor analyses. We refer to these four main EFA factors as management attitudes (Table 3). The first factor was influenced by statements that supported fish stocking; we named this 
the "pro-stocking" management attitude. The second factor represented items that indicated respondents either had no opinion or did not feel informed enough on the issue. This "neutral" management attitude was not included as a response variable in our models, since we were primarily interested in what drives attitude (versus a lack thereof). The third factor represented items expressing concern over fish stocking and beliefs that action should be taken; we named this third factor the "pro-preservation" management attitude. Last, the fourth management attitude was represented by the remaining item with a substantial factor loading - that some lakes should be kept pristine while others should be managed as a fishery. We named this "pro-conservation" management attitude (represented by a single measured item; hence no $\alpha$ ).

Table 3 Factors and factor loadings of mountain lakes fisheries management attitude statements $(\mathrm{N}=392)$. Bold indicates a strong contribution to the respective factor. Total variance explained $=47 \%$

\begin{tabular}{|c|c|c|c|c|}
\hline $\begin{array}{l}\text { "How much do you } \\
\text { agree/disagree with each } \\
\text { statement?" }\end{array}$ & $\begin{array}{l}\text { Pro- } \\
\text { stocking } \\
\text { Factor } 1\end{array}$ & $\begin{array}{l}\text { Neutral } \\
\text { Factor } 2\end{array}$ & $\begin{array}{c}\text { Pro- } \\
\text { preservation } \\
\text { Factor } 3\end{array}$ & $\begin{array}{c}\text { Pro- } \\
\text { conservation } \\
\text { Factor } 4\end{array}$ \\
\hline $\begin{array}{l}\text { The benefits of stocking } \\
\text { outweigh the ecological } \\
\text { consequences }\end{array}$ & 0.62 & 0.19 & -0.16 & 0.22 \\
\hline $\begin{array}{l}\text { Fish add value to all } \\
\text { mountain lakes, despite } \\
\text { potential concerns }\end{array}$ & 0.69 & 0.23 & -0.23 & 0.21 \\
\hline $\begin{array}{l}\text { People keep blowing } \\
\text { environmental issues out } \\
\text { of proportion; this is } \\
\text { another example }\end{array}$ & 0.64 & 0.26 & -0.16 & 0.21 \\
\hline $\begin{array}{l}\text { Stocking programs } \\
\text { should be reinstated }\end{array}$ & 0.70 & 0.22 & -0.30 & 0.32 \\
\hline I don't have an opinion & 0.33 & 0.63 & 0.00 & 0.00 \\
\hline
\end{tabular}




\begin{tabular}{|c|c|c|c|c|}
\hline $\begin{array}{l}\text { I don't feel informed } \\
\text { enough to have an } \\
\text { opinion }\end{array}$ & 0.22 & 0.73 & 0.00 & 0.00 \\
\hline $\begin{array}{l}\text { The concerns of fish } \\
\text { stocking are legitimate }\end{array}$ & -0.32 & -0.26 & 0.64 & 0.00 \\
\hline $\begin{array}{l}\text { Action should be taken } \\
\text { to alleviate the effects of } \\
\text { fish on all mountain lakes }\end{array}$ & -0.13 & -0.30 & 0.63 & -0.47 \\
\hline $\begin{array}{l}\text { Some lakes should be } \\
\text { designated for fishing, } \\
\text { other for pristine nature }\end{array}$ & 0.26 & 0.20 & 0.00 & 0.70 \\
\hline $\begin{array}{l}\text { Removing fish is an } \\
\text { appropriate restoration } \\
\text { approach }\end{array}$ & -0.32 & -0.43 & 0.29 & -0.27 \\
\hline $\begin{array}{l}\text { Removing fish from some } \\
\text { will increase pressure on } \\
\text { those that still have fish }\end{array}$ & 0.00 & 0.00 & 0.00 & 0.20 \\
\hline $\begin{array}{l}\text { Removing fish will be just } \\
\text { as harmful as keeping } \\
\text { fish in the lakes }\end{array}$ & 0.50 & 0.30 & -0.15 & 0.30 \\
\hline $\begin{array}{l}\text { Fish should be removed, } \\
\text { but only using manual } \\
\text { methods (no chemicals) }\end{array}$ & - & 0.17 & 0.35 & 0.00 \\
\hline Eigenvalue & 2.53 & 1.63 & 1.23 & 1.16 \\
\hline $\begin{array}{l}\text { Percent Variance } \\
\text { Explained }\end{array}$ & 0.20 & 0.13 & 0.09 & 0.09 \\
\hline Cronbach's $\alpha^{1}$ & 0.85 & 0.70 & 0.72 & $\mathrm{n} / \mathrm{a}$ \\
\hline Mean index score & -0.59 & -0.17 & 0.86 & 0.29 \\
\hline
\end{tabular}

\subsection{Drivers of visitor attitudes}

To capture the effects of visitor ranking of the importance of national park waterbodies and ecological knowledge on visitor attitudes, we created four composite index variables using the EFA results. Three of these indices described the perceived value of waterbodies (Table 4), and one represented knowledge of park nature. Responses to the importance of national park waterbodies grouped into three factors, which we named ecological importance, cultural 
importance, and recreational importance (Table 4). The fourth composite variable, i.e., "knowledge", consisted of the average self-ranked knowledge scores for all aspects of park nature and management (Supplementary Material 3). In our models, we excluded the cultural importance of waterbodies index due to its correlation with the ecological importance index (Pearson's $r=0.72)$.

Table 4 Factors and factor loadings for beliefs related to NP waterbody importance ( $N=$ 361). Bold indicates a strong contribution to the respective factor. Total variance explained $=61 \%$

\begin{tabular}{l|ccc}
\hline $\begin{array}{l}\text { "NP waterbodies are } \\
\text { important for..." }\end{array}$ & $\begin{array}{c}\text { Ecological } \\
\text { importance } \\
\text { Factor } 1\end{array}$ & $\begin{array}{c}\text { Cultural } \\
\text { importance } \\
\text { Factor 2 }\end{array}$ & $\begin{array}{c}\text { Recreational } \\
\text { importance } \\
\text { Factor 3 }\end{array}$ \\
\hline $\begin{array}{l}\text { Recreation } \\
\text { Clean water }\end{array}$ & 0.22 & 0.13 & 0.69 \\
Preserving biodiversity & 0.57 & 0.24 & 0.23 \\
Fishing & 0.00 & 0.19 & 0.00 \\
Intrinsic/existence value & 0.37 & 0.16 & 0.62 \\
Culture & 0.18 & 0.51 & 0.15 \\
\hline Eigenvalue & 1.50 & 1.14 & 0.23 \\
Percent Variance Explained & 0.25 & 0.19 & 0.17 \\
Cronbach's $\alpha^{1}$ & 0.76 & 0.70 & 0.63 \\
Mean index score & 1.75 & 1.47 & 1.34
\end{tabular}

${ }^{1}$ Cronbach's $\alpha$ was computed for items with substantial (bold) factor loadings (threshold $=0.50$ ).

Instead of creating a composite variable for perceived ecosystem threats, we chose to average scores for one threat - climate change. We chose this threat because respondents' social norms and value-orientations are likely to influence their perceptions of climate change 
risk (e.g. van der Linden, 2015). We also selected one representative attitude statement "Stocking mountain lakes in the park with fish is important for recreation" - to characterize stocking attitude (mean index score $=-0.07$ ). Last, we sorted responses about group membership into three types. Ecological groups included those who participate in environmental activism, education, and/or conservation, e.g., The Nature Conservancy or Sierra Club. Recreational groups are those who primarily serve as a resource for outdoor recreation, such as The Mountaineers (a Washington-based mountaineering club), or the American Alpine Club. Resource groups included those organizations primarily focused on managing a specific resource for recreational purposes, such as Trout Unlimited or the Rocky Mountain Elk Foundation (Table 2).

For each model, final predictor variables included demographic data, self-ranked environmental knowledge, ecological and recreational waterbody importance, attitude toward national park ecosystem health, attitude toward the threat of climate change, prior knowledge of historical fish stocking, group membership type, initial attitude toward fish presence, and participation in angling. All model predictor variables met logistic regression assumptions for independence, based on a covariance matrix test and $\chi^{2}$ test of independence for categorical variables.

\subsubsection{Model results}

All three of the logistic regressions capturing management attitudes performed significantly better than a null model $\left(\chi^{2}<0.01 ;\right.$ Table 5). A pro-stocking attitude among visitors was best determined by gender, education, recreational value, opinion of ecosystem health, 
opinion of the threat of climate change, and initial opinion of stocking $\left(\chi^{2}=29.9, p<0.001\right.$, pseudo $\left.R^{2}=0.32\right)$. All of these variables were significant $(\alpha<0.05)$ in our final logistic model, with the exception of recreational value and gender, which showed marginal significance $(\alpha<0.10)$. Respondents with lower levels of education were more likely to hold pro-stocking attitudes. In addition, pro-stocking respondents were more likely to view national park ecosystems as healthy and were less likely to view climate change as a threat. Respondents who initially viewed fish stocking positively, before reading the excerpt, were also more likely to maintain a pro-stocking attitude. A weak relationship with gender suggests that respondents who support fish stocking in mountain lakes were more likely to be male (Table 5).

Pro-preservation attitudes were associated with the park at which respondents were visiting, level of education, self-ranked knowledge, recreational importance of lakes, opinion of national park ecosystem health, initial opinion of stocking, and group membership $\left(\chi^{2}=23.6, p\right.$ $=0.001$, pseudo $\left.R^{2}=0.41\right)$. All variables were significant in our final logistic model $(\alpha<0.05)$, with the exception of education, which was marginally significant $(\alpha<0.10)$. Respondents visiting Mount Rainer NP and those with low self-ranked knowledge about park ecosystems were more likely to agree with pro-preservation sentiments. In addition, those who rated lakes as being important for recreation, but did not feel national park ecosystems were healthy, were more likely to support the pro-preservation attitude. Pro-preservation attitudes were also expressed by respondents who had an initially negative view of stocking, prior to reading the excerpt, and by respondents who were not members of natural resource-oriented groups. The model also suggests that those with higher levels of education may be more likely to support a propreservation management approach, but this variable was only marginally significant. 
Pro-conservation attitudes were associated with respondent age, opinion of the threat of climate change, prior knowledge and initial opinion of stocking practices, and participation in angling $\left(\chi^{2}=41.5, p<0.001\right.$, pseudo $\left.R^{2}=0.32\right)$. All of these variables were significant in our final logistic model $(\alpha<0.05)$, with the exception of age, which was marginally significant $(\alpha<0.10)$. Respondents who agreed with a pro-conservation management approach were unlikely to view climate change as a threat to national park ecosystems. In addition, pro-conservation attitudes were expressed by those who did not have prior knowledge of fish stocking in mountain lakes, but viewed it positively. These respondents were also more likely to participate in angling. The negative relationship with age in our model suggests younger respondents may be more likely to support a conservation approach.

Table 5 Logistic regression model results for predicting positive attitudes toward three mountain lake fisheries management approaches: pro-stocking $(n=303)$, pro-conservation $(n=220)$, and pro-preservation $(n=291)$. Management attitudes were coded as binary $(1 \mid 0)$

\begin{tabular}{|c|c|c|c|c|c|c|c|c|c|}
\hline \multirow[b]{2}{*}{ Variables } & \multicolumn{3}{|c|}{$\begin{array}{l}\text { Pro-stocking model } \\
\text { Pseudo } R^{2}=0.32 \\
\chi^{2}<0.01\end{array}$} & \multicolumn{3}{|c|}{$\begin{array}{l}\text { Pro-preservation model } \\
\text { Pseudo } R^{2}=0.41 \\
\chi^{2}<0.01\end{array}$} & \multicolumn{3}{|c|}{$\begin{array}{l}\text { Pro-conservation model } \\
\text { Pseudo } R^{2}=0.32 \\
\chi^{2}<0.01\end{array}$} \\
\hline & $B( \pm S E)$ & $Z$ & $p$ & $B( \pm S E)$ & $Z$ & $p$ & $\beta( \pm S E)$ & $Z$ & $p$ \\
\hline $\begin{array}{l}\text { Mount Rainier } \\
\text { NP }\end{array}$ & --- & --- & --- & $\begin{array}{l}2.16 \\
( \pm 0.87)\end{array}$ & 2.49 & $0.01^{*}$ & --- & --- & -- \\
\hline Age & --- & --- & --- & --- & --- & --- & $\begin{array}{l}-0.02 \\
( \pm 0.01)\end{array}$ & -1.81 & 0.07 \\
\hline Male & $\begin{array}{l}0.77 \\
( \pm 0.43)\end{array}$ & 1.78 & 0.07 & --- & --- & --- & --- & --- & --- \\
\hline Education & $\begin{array}{l}-0.39 \\
( \pm 0.19)\end{array}$ & -2.04 & $0.04^{*}$ & $\begin{array}{l}0.71 \\
( \pm 0.40)\end{array}$ & 1.78 & 0.07 & --- & --- & --- \\
\hline $\begin{array}{l}\text { Ecological } \\
\text { knowledge }\end{array}$ & --- & --- & --- & $\begin{array}{l}-1.05 \\
( \pm 0.48)\end{array}$ & -2.20 & $0.03 *$ & --- & --- & --- \\
\hline $\begin{array}{l}\text { Recreation } \\
\text { importance }\end{array}$ & $\begin{array}{l}0.54 \\
( \pm 0.35)\end{array}$ & 1.55 & 0.12 & $\begin{array}{l}1.58 \\
( \pm 0.54)\end{array}$ & 2.90 & $<0.01^{* *}$ & --- & --- & --- \\
\hline
\end{tabular}




\begin{tabular}{|c|c|c|c|c|c|c|c|c|c|}
\hline $\begin{array}{l}\text { Ecological } \\
\text { health }\end{array}$ & $\begin{array}{l}0.58 \\
( \pm 0.24)\end{array}$ & 2.38 & $0.02 *$ & $\begin{array}{l}-1.02 \\
( \pm 0.46)\end{array}$ & -2.23 & $0.03 *$ & --- & -- & -- \\
\hline $\begin{array}{l}\text { Climate change } \\
\text { opinion }\end{array}$ & $\begin{array}{l}-0.82 \\
( \pm 0.19)\end{array}$ & -4.38 & $<0.01 * * *$ & --- & --- & --- & $\begin{array}{l}-1.03 \\
( \pm 0.40)\end{array}$ & -2.60 & $0.01^{*}$ \\
\hline $\begin{array}{l}\text { Stocking } \\
\text { knowledge }\end{array}$ & --- & --- & --- & --- & --- & --- & $\begin{array}{l}-1.05 \\
( \pm 0.45)\end{array}$ & -2.36 & $0.02 *$ \\
\hline $\begin{array}{l}\text { Stocking } \\
\text { opinion }\end{array}$ & $\begin{array}{l}0.94 \\
( \pm 0.23)\end{array}$ & 4.07 & $<0.01 * * *$ & $\begin{array}{l}-1.59 \\
( \pm 0.45)\end{array}$ & -3.57 & $<0.01^{* * *}$ & $\begin{array}{l}1.17 \\
( \pm 0.23)\end{array}$ & 5.03 & $\begin{array}{l}<0.01^{* *} \\
*\end{array}$ \\
\hline Angler & --- & --- & --- & --- & --- & --- & $\begin{array}{l}1.30 \\
( \pm 0.52)\end{array}$ & 2.53 & $0.01^{*}$ \\
\hline $\begin{array}{l}\text { Resource } \\
\text { group }\end{array}$ & --- & --- & --- & $\begin{array}{l}-7.95 \\
( \pm 1.97)\end{array}$ & -4.03 & $<0.01^{* * *}$ & --- & --- & --- \\
\hline
\end{tabular}

$* p<0.05, * * p<0.01, * * * p<0.001$

\subsection{Visitor fish consumption}

Our survey found that that $43.5 \%$ of respondents who participate in angling report consuming mountain lake fish on at least one occasion annually, which equates to $12.7 \%$ of survey respondents (Fig. 2). Extrapolating these results to 2017 annual park recreation visitation indicates that roughly 153,300 visitors at Mount Rainier and 4,400 visitors at North Cascades NP (113,900 if including Ross Lake National Recreation Area) may consume mountain lake fish on at least one occasion each year. However, it should be noted that these figures do not take into account that our survey sample may not be entirely representative of the visitor population at each park. For instance, the value at Mount Rainier NP may be inflated because a sizable proportion of visitors to the park are part of large tour bus groups, who were underrepresented in our data collection. However, we tried to alleviate for this by only using total number of visitors who were reported to be recreating by the NPS (National Parks Service, 2017). 


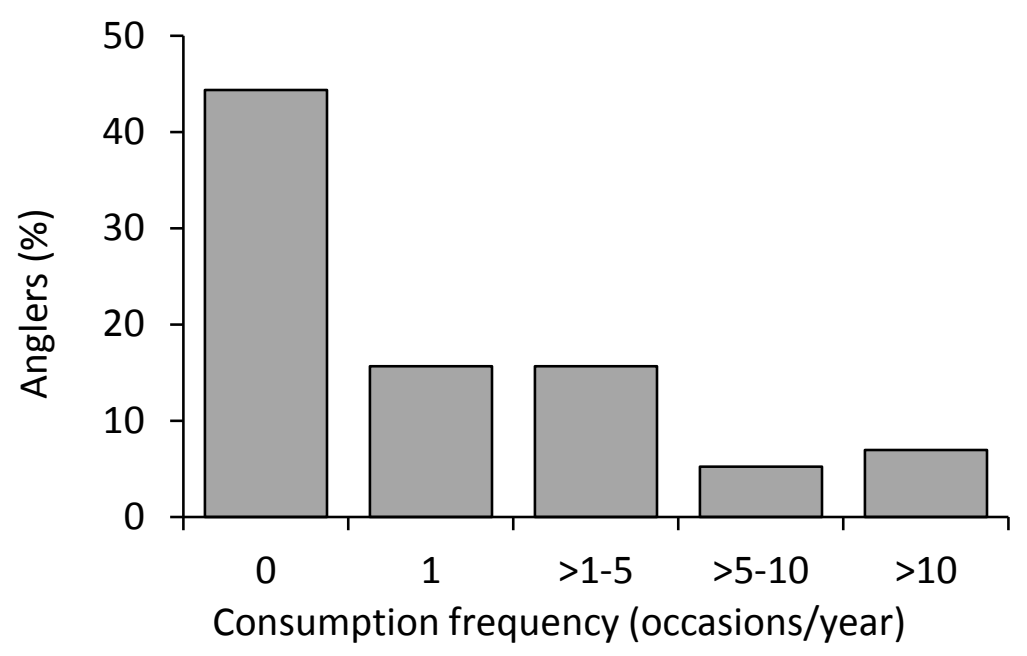

Fig. 2 Annual fish consumption frequency of angler respondents.

\section{Discussion}

Historical fish stocking on US public lands has created a challenging management predicament. The cultural importance of mountain lake fishing is at odds with scientific and federal land management objectives - especially in wilderness areas (Landres et al., 2001). Mountain lake fisheries management issues have had little public exposure, leaving a major knowledge gap about public perceptions. This lack of data about public perceptions is a common problem in wilderness management (Watson et al., 2015). Our research indicates that visitors' attitudes toward mountain lake fisheries management are diverse, and are driven primarily by visitors' knowledge of ecological issues, recreational habits, social norms, and value-orientations.

\subsection{Visitor attitudes toward fisheries management approaches}


As we hypothesized, the emergence of the four fisheries management attitudes - prostocking, pro-conservation, pro-preservation, and neutral - from our data aligns well with Teel and Manfredo's (2010) four major wildlife-value orientation groups - traditionalist, pluralist, mutualist, and distant, respectively. On either end of this attitude spectrum, the pro-stocking and pro-preservation attitude groups support two primary theoretical value orientations: anthropocentric and biocentric (e.g. McFarlane and Boxall, 2000; Steel et al., 1994; Vaske and Donnelly, 1999).

Based on our results, the attitudes of the majority of national park visitors are aligned with those of the scientific community and the National Parks Service, as most respondents agreed that managers should take action to reduce the negative effects of historical fish stocking in mountain lakes. Our observed support for restorative management actions makes sense in the context of a study by Duffus and Dearden (1990), which summarizes a shift from consumptive to non-consumptive wildlife recreation. The shift to non-consumptive uses has grown since the 1990s, with a documented steady decline in hunting and angling licenses while hiking and backpacking is on the rise (Pergams and Zaradic, 2008). With the growth of nonconsumptive recreation, it seems intuitive that the majority of visitors viewed preservationoriented management approaches favorably, since, for example, healthy ecosystems are required for wildlife viewing. Watson et al. (2015) demonstrate this phenomenon with their study of visitors at Sequoia and Kings NP in California: respondents broadly supported management actions that would restore park ecosystems to natural conditions.

Notably, while taking action was a popular approach, about half of those respondents who supported management actions to remove fish did not agree with the use of chemical 
removal techniques. This attitude could be due in part to these respondents' lack of knowledge about piscicides and the precautions that agency managers take when using these chemicals this information was not included in the questionnaire. Alternatively, the lack of support for this approach may be because attitudes in support of "severe" (i.e. lethal) interventions are typically only driven by strong value-orientations, or only exist for wildlife issues that have a potentially negative implication for humans (Jacobs et al., 2014).

\subsection{Drivers of management attitudes}

Contrary to our expectations, pro-preservation attitudes were associated with low selfranked ecological knowledge. However, this attitude was associated with a higher level of education. That pro-preservation attitudes are associated with higher rankings for the recreational importance of waterbodies is surprising, because this composite variable includes fishing as an important aspect. We also expected perceived climate change threat to be an important predictor of the pro-preservation attitude, but it was not significant. Our results may be explained by Sharp et al. (2011), who found that while knowledge and perceived threat scores influenced invasive species management preferences, environmental attitudes were the best indicator of management action support. However, the influence of group membership, perception of ecological health, and initial opinion of stocking on pro-preservation attitudes do support our hypotheses. Mount Rainier NP visitors may have been more likely to support a preservation attitude, because of the interpretive material about the issue of mountain lake fisheries in at least one of their visitor centers. The conflicting findings for this attitude group may indicate that our belief statements may not have effectively captured the types of 
attitudes held by those who are in favor of restoration. This is perhaps due to the complexity of values that lead to support for lethal wildlife management approaches (e.g. Jacobs et al., 2014). Respondents with pro-stocking attitudes were more likely to report lower degree levels obtained than those who supported fish removal actions, recreation as an important aspect of waterbodies, perceive park ecosystems as healthy, and were unlikely to perceive climate change as a threat to ecosystems. Similar results regarding education were found in a study on attitudes toward wolf reintroductions - those who were less educated were less likely to view wolves and their reintroduction as favorable, despite their ecological benefit (Williams et al., 2016). Additionally, due to the importance of environmental education in determining one's level of environmentally responsible behavior (Hungerford and Volk, 1990), it is not surprising that pro-stocking attitudes were associated with lower education. The importance of positive initial attitudes about stocking in this group indicates that respondents with a pro-stocking management attitude were unlikely to be swayed by the excerpt on the ecological effects of fish (Supplementary Material 1).

Based on Teel and Manfredo's (2010) description of pluralist wildlife-value orientations, we expected pro-conservation attitudes to align with both recreational and ecological waterbody importance, but this was not the case. Respondents with pro-conservation attitudes were likely to have a positive initial view of stocking, and not perceive climate change as a threat to ecosystem health. Pro-conservation respondents were also less likely to have prior knowledge of fish stocking in mountain lakes. Perhaps this indicates that pro-conservation respondents were less likely to have pre-determined attitudes about the issue, which could explain why they were more likely to indicate a more moderate, conservation-based attitude 
after reading the excerpt, despite having an initially positive view of stocking. In addition, angling participation was associated with a pro-conservation attitude. This may be explained by the fact that angling license programs (along with hunting license programs) are founded on the principle of conservation - where fees from licenses allowing for wildlife harvest sustain the funding for wildlife conservation (e.g. Duda et al., 2010; Heffelfinger et al., 2013)

\subsection{Contaminant precautions}

Although the percentage of visitors in our study who consume fish from mountain lakes annually is small (4\%), our extrapolation suggests that many thousands of visitors to mountain lakes at national parks, national forests, and other public lands may consume fish every year. Considering that levels of many industrial compounds can sometimes exceed US EPA consumption thresholds in existing studies of mountain lake fishes (e.g. Ackerman et al., 2008; Blais et al., 2006; Flanagan Pritz et al., 2014; Landers et al., 2008), fish consumption patterns may be an important focus for managers. Current available research can be used to provide visiting anglers with the best-available knowledge to mitigate against contaminant exposure (e.g. Clayden et al., 2013; Drenner et al., 2013; Flanagan Pritz et al., 2014; Ullrich et al., 2001). For example, Chiapella and Strecker (2016) found that rainbow trout, as well as fish from large, deep lakes, had the lowest mercury levels across several national parks. Informed anglers should be able to identify factors that increase the risk of contamination when choosing which lakes to consume fish from. By using proper education and outreach, managers could lower the risk of contaminant consumption by anglers. 


\subsection{A balanced and participatory approach}

Although many respondents agreed with a management approach that prioritizes ecological health, we found that angling is still a popular activity, and many non-anglers have interest in participating. About one-third of respondents indicated that they have fished in national parks or on other lands at some point, and about $15 \%$ who have not fished on public lands would be interested in doing so in the future. Angling is expected to increase in prevalence due to population growth, despite per capita decreases in participation (Bowker et al., 2012; Cordell et al., 2008). This trend could help explain why a pro-conservation attitude was common among respondents.

This interest in angling, paired with the broad support for conservation-based management by our respondents indicates that a management plan that optimizes ecological integrity using fish removal, but still allows for fishing in less sensitive lakes, could be a popular option for both the average visitor and the angling community alike. Such a balanced approach could also help mitigate illegal stocking, which has been observed after fish removals in North Cascades, Mount Rainier, and Yosemite NP, and is an inconvenient yet unavoidable risk (Halverson, 2011; National Parks Service, 2017, 2007; Pister, 2001). The combined interest in angling and concern for ecological health from visitors could also be leveraged in the fish removal effort. Education and outreach, especially at wilderness permitting stations, could be an effective means of recruiting visitors to help with manual fish removal efforts by encouraging angling (with the requirement of removal) in mountain lakes with fish. However, using visitors to help with removal would have to be used with caution, to avoid creating a longterm incentive for fishing in systems where total fish eradication is the ultimate goal. If 
implemented with care, the inclusion of citizen anglers in the management of mountain lakes fisheries would be useful not just with fish removal efforts. Citizen science can also be an important component of education, outreach, and engagement of the public in the management and decision-making process (McKinley et al., 2017). Additionally, based on previous success with educational and interpretive programs on public lands (Marion and Reid, 2009), parks could likely garner more support for fish removal using these methods, as long as they are targeted to appeal to the diverse value-orientations of visitors (Miller et al., 2017).

Other examples of major food-web restoration efforts on public lands illustrate that social considerations of management actions are crucial to successful implementation. For instance, the reintroduction of beaver populations on public lands in the Pacific Northwest could restore ecological complexity and resilience in aquatic ecosystems, but has suffered roadblocks due to opposing interests between agricultural, management, and scientific groups (Baldwin, 2017). The re-introduction of wolves in Yellowstone NP would not have been possible without balancing the values and concerns of stakeholders (Bath, 1989; Fritts et al., 1997). Similarly, for successful management and restoration of mountain lakes, it will be crucial for managers to consider mountain lakes as a complex socioecological system, which requires not just ecological monitoring, but engagement with stakeholders and the public to optimize decision-making and management best practices (Alessa et al., 2018).

\subsection{Bias and caveats}

In line with past visitor surveys (e.g. Floyd, 1999; Ghimire et al., 2016; U.S. Forest Service, 2016), the majority of visitors were white, leaving the viewpoints of minority groups 
vastly underrepresented. Although they only make up a small percentage of visitors, the viewpoints of people of color and Native Americans are important to consider, since they likely have distinct opinions about public lands management (Floyd, 1999; Johnson et al., 2004; Krymkowski et al., 2014; Washburne, 1978). In addition, national parks are putting effort into increasing the visitation of diverse visitor populations (e.g. McGown et al., 2012). Capturing the perceptions of minority groups on the issue of mountain lakes fisheries management could be an important aspect of the decision-making process, especially if parks want to prioritize visitation accessibility to marginalized communities.

In addition to minority groups, families with small children were also underrepresented by this survey. Although the viewpoints of this demographic are unlikely to differ as drastically as those of minority groups, they may be more at-risk of exposure to contaminants relative to the average visitor portrayed by this study. Many of the toxins that have been detected in mountain lake fish are more harmful during early developmental stages, such as mercury, which is a neurotoxin (Agency for Toxic Substances and Disease Registry, 2011). The consumption of fish in these lakes by families and their children is something that should be considered in management decisions.

\section{Conclusions}

While the attitudes of public lands visitors alone should not dictate management decisions, the decision-making process in public lands and wilderness management often fails to effectively capture public viewpoints (Watson et al., 2015). We found that a balanced management plan that implements fish eradication in lakes with sensitivity to fish presence, but 
leaves populations in lakes that are more resilient, while also engaging visitors in outreach and the fish removal process would be the best approach to creating a balance between stakeholder attitudes. This strategy would provide a compromise for those who value angling in mountain likes, while still promoting the ecological health of mountain ecosystems, which was the most important aspect of lakes according to our survey, and the most important value of wilderness according to other research (Brown and Alessa, 2005; Cordell et al., 1998).

We anticipate these findings are relevant not just for national parks, but for many land management agencies in the US and abroad. Trout are the one most ubiquitously stocked fish in the world, and have been introduced into mountain lakes ranging from the Sierras, Cascades, and Rockies (Knapp et al., 2001; Pister, 2001), to the Andes (Vigliano et al., 2009), Alps, and Pyrenees (Tiberti et al., 2014). Bennett et al. (2016) argue that the inclusion of social science and public values is imperative in management and conservation decisions, and this no doubt applies to a conservation issue as large as fish stocking. Our study provides a foundation for how to incorporate views of the public into the management and conservation of mountain lakes, and we encourage future studies to build upon this foundation.

All procedures performed in studies involving human participants were in accordance with the ethical standards of the institutional and/or national research committee and with the 1964 Helsinki declaration and its later amendments or comparable ethical standards.

\section{Acknowledgements}

This research was made possible thanks to support from Regina Rochefort, Ashley Rawhouser, and Rebecca Lofgren. We thank three anonymous reviewers for constructive feedback. Funding: this work was supported by the Edward D. and Olive C. Bushby Scholarship; the 
National Science Foundation Graduate Research Fellowship Program [grant \# 1638278]; and the National Science Foundation Integrative Graduate Education and Research Traineeship [grant \#0966376: “Sustaining Ecosystem Services to Support Rapidly Urbanizing Regions]. Any opinions, findings, and conclusions or recommendations expressed in this material are those of the authors and do not necessarily reflect the views of the National Science Foundation. 


\section{References}

Ackerman, L.K., Schwindt, A.R., Simonich, S.L.M., Koch, D.C., Blett, T.F., Schreck, C.B., Kent, M.L., Landers, D.H., 2008. Atmospherically deposited PBDEs, pesticides, PCBs, and PAHs in western U.S. National Park fish: concentrations and consumption guidelines. Environ. Sci. Technol. 42, 2334-41. https://doi.org/10.1021/es702348j

Adams, S.B., Frissell, C.A., Rieman, B.E., 2001. Geography of invasion in mountain streams: Consequences of headwater lake fish introductions. Ecosystems 4, 296-307. https://doi.org/10.1007/s10021-001-0012-5

Agency for Toxic Substances and Disease Registry, 2011. Toxic Substances - Mercury [WWW Document]. Dep. Heal. Hum. Serv. URL https://www.atsdr.cdc.gov/substances/toxsubstance.asp?toxid=24 (accessed 3.19.18).

Alessa, L., Kliskey, A., Gosz, J., Griffith, D., Ziegler, A., 2018. MtnSEON and social-ecological systems science in complex mountain landscapes. Front. Ecol. Environ. 16, S4-S10. https://doi.org/10.1002/fee.1753

Baldwin, J., 2017. Institutional Obstacles to Beaver Recolonization and Potential Climate Change Adaptation in Oregon, USA. Assoc. Pacific Coast Geogr. Yearb. 79, 93-114. https://doi.org/10.1353/pcg.2017.0005

Bath, A.J., 1989. The public and wolf reintroduction in Yellowstone National Park. Soc. Nat. Resour. 2, 297-306. https://doi.org/10.1080/08941928909380693

Bennett, N.J., Roth, R., Klain, S.C., Chan, K., Christie, P., Clark, D.A., Cullman, G., Curran, D., Durbin, T.J., Epstein, G., Greenberg, A., Nelson, M.P., Sandlos, J., Stedman, R., Teel, T.L., Thomas, R., Veríssimo, D., Wyborn, C., 2016. Conservation social science: Understanding and integrating human dimensions to improve conservation. Biol. Conserv. 205, 93-108. https://doi.org/10.1016/j.biocon.2016.10.006

Blais, J.M., Charpentié, S., Pick, F., Kimpe, L.E., St Amand, A., Regnault-Roger, C., 2006. Mercury, polybrominated diphenyl ether, organochlorine pesticide, and polychlorinated biphenyl concentrations in fish from lakes along an elevation transect in the French Pyrénées. Ecotoxicol. Environ. Saf. 63, 91-9. https://doi.org/10.1016/j.ecoenv.2005.08.008

Borrie, W.T., Freimund, W.A., Davenport, M.A., 2002. Winter Visitors to Yellowstone National Park : Their Value Orientations and Support for Management Actions. Hum. Ecol. 41-48.

Bowker, J.M., Askew, A.E., Cordell, H.K., Betz, C.J., Zarnoch, S.J., Seymour, L., 2012. Outdoor Recreation Participation in the United States - Projections to 2060.

Bradford, D.F., Cooper, S.D., Jenkins, Jr., T.M., Kratz, K., Sarnelle, O., Brown, A.D., 1998. Influences of natural acidity and introduced fish on faunal assemblages in California alpine lakes. Can. J. Fish. Aquat. Sci. 55, 2478-2491. https://doi.org/10.1139/f98-128

Brehm, J.M., Eisenhauer, B.W., Krannich, R.S., 2004. Dimensions of Community Attachment and Their Relationships to Well-Being in the Amenity Rich Rural West. Rural Sociol. 69, 405429.

Brown, B.Y.G., Alessa, L., 2005. A GIS - based Inductive Study of Wilderness Values. Int. J. Wilderness 11, 1-5.

Carlisle, D.M., Hawkins, C.P., 1998. Relationships between Invertebrate Assemblage Structure , 2 Trout Species, and Habitat Structure in Utah Mountain Lakes. J. North Ameican Benthol. Soc. 17, 286-300. https://doi.org/10.2307/1468332

Chiapella, A., Strecker, A., 2016. A stable isotope approach to understanding contaminant 
distribution in food webs of montane lakes.

Clayden, M.G., Kidd, K. a., Wyn, B., Kirk, J.L., Muir, D.C.G., O’Driscoll, N.J., 2013. Mercury biomagnification through food webs is affected by physical and chemical characteristics of lakes. Environ. Sci. Technol. 47, 12047-12053. https://doi.org/10.1021/es4022975

Cordell, H.., Tarrant, M.A., McDonald, B.., Bergstrom, J.C., 1998. How the public views wilderness. Int. J. Wilderness 4, 28-31.

Cordell, H.K., Betz, C.J., Green, G.T., 2008. Nature-based Outdoor Recreation Trends and Wilderness. Int. J. Wilderness 14, 7-10.

Daigle, J.J., Hrubes, D., Ajzen, I., 2002. A Comparative Study of Beliefs, Attitudes, and Values Among Hunters, Wildlife Viewers, and Other Outdoor Recreationists. Hum. Dimens. Wildl. 7, 1-19. https://doi.org/10.1080/108712002753574756

DeAngelo, M., Nielsen-Pincus, M., 2017. Choosing the Right Policy Tools to Encourage Watershed Stewardship through the Study of Attitude. Soc. Nat. Resour. 30, 1328-1342. https://doi.org/10.1080/08941920.2017.1347973

Drenner, R.W., Chumchal, M.M., Jones, C.M., Lehmann, C.M.B., Gay, D. a, Donato, D.I., 2013. Effects of mercury deposition and coniferous forests on the mercury contamination of fish in the south central United States. Environ. Sci. Technol. 47, S:1-7. https://doi.org/10.1021/es303734n

Duda, M., Jones, M., Criscione, A., 2010. The sportsman's voice: Hunting and fishing in America. Duffus, D.A., Dearden, P., 1990. Non-consumptive wildlife-oriented recreation: A conceptual framework. Biol. Conserv. 53, 213-231. https://doi.org/10.1016/0006-3207(90)90087-6

Eby, L. a, Roach, W.J., Crowder, L.B., Stanford, J. a, 2006. Effects of stocking-up freshwater food webs. Trends Ecol. Evol. 21, 576-84. https://doi.org/10.1016/j.tree.2006.06.016

English, D.B.K., Kocis, S.M., Zarnoch, S.J., Arnold, J.R., 2002. Forest Service National Visitor Use Monitoring Process: Research Method Documentation.

Epanchin, P.N., Knapp, R. a, Lawler, S.P., 2010. Nonnative trout impact an alpine-nesting bird by altering aquatic-insect subsidies. Ecology 91, 2406-15. https://doi.org/https://doi.org/10.1890/09-1974.1

Finlay, J.C., Vredenburg, V.T., 2007. Introduced trout sever trophic connections in watersheds: consequences for a declining amphibian. Ecology 88, 2187-98. https://doi.org/https://doi.org/10.1890/06-0344.1

Flanagan Pritz, C., Eagles-smith, C., Krabbenhoft, D., 2014. Mercury in the National Parks. George Wright Forum 31, 168-180.

Floyd, M.F., 1999. Race, ethnicity and use of the National Park System. Soc. Sci. Res. Rev. 1, 124. https://doi.org/10.1111/j.1469-7610.2011.02477.x

Fritts, S.H., Bangs, E.E., Fontaine, J. a, Johnson, M.R., Phillips, M.K., Koch, E.D., Gunson, J.R., 1997. Planning and Implementing a Reintroduction of Wolves to Yellowstone National Park and Central Idaho. Restor. Ecol. 5, 7-27. https://doi.org/10.1046/j.1526100X.1997.09702.x

Fulton, D.C., Manfredo, M.J., Lipscomb, J., 1996. Wildlife value orientations: A conceptual and measurement approach. Hum. Dimens. Wildl. 1, 24-47. https://doi.org/10.1080/10871209609359060

Ghimire, R., Green, G.T., Poudyal, N.C., Cordell, H.K., 2016. Who Recreates Where : Implications from a National Recreation Household Survey. Jounral For. 114, 458-465. 
https://doi.org/https://doi.org/10.5849/jof.14-106

Hall, T.E., Seekamp, E., Cole, D., 2010. Do recreation motivations and wilderness involvement relate to support for wilderness management? A segmentation analysis. Leis. Sci. 32, 109124. https://doi.org/10.1080/01490400903547096

Halverson, A., 2011. Chasing Rainbows. Conserv. Mag.

Heffelfinger, J.R., Geist, V., Wishart, W., 2013. The role of hunting in North American wildlife conservation. Int. J. Environ. Stud. 70, 399-413. https://doi.org/10.1080/00207233.2013.800383

Hungerford, H.R., Volk, T.L., 1990. Changing learner behavior through environmental education. J. Environ. Educ. https://doi.org/10.1080/00958964.1990.10753743

Jackman, S., 2015. pscl: Classes and methods for R developed in the political science computational laboratory, Stanford University.

Jacobs, M.H., Vaske, J.J., Sijtsma, M.T.J., 2014. Predictive potential of wildlife value orientations for acceptability of management interventions. J. Nat. Conserv. https://doi.org/10.1016/j.jnc.2014.03.005

Johnson, C.Y., Bowker, J.M., Bergstrom, J.C., Cordell, H.K., 2004. Wilderness Values in America: Does Immigrant Status or Ethnicity Matter? Soc. Nat. Resour. 17, 611-628. https://doi.org/10.1080/08941920490466585

Knapp, R.A., Corn, P.S., Schindler, D.E., 2001. The Introduction of Nonnative Fish into Wilderness Lakes : Good Intentions, Conflicting Mandates, and Unintended Consequences. Ecosystems 4, 275-278. https://doi.org/10.1007/s10021

Knapp, R.A., Matthews, K.R., 2000. Non-Native Fish Introductions and the Decline of the Mountain Yellow-Legged Frog from within Protected Areas. Conserv. Biol. 14, 428-438.

Krymkowski, D.H., Manning, R.E., Valliere, W.A., 2014. Race, ethnicity, and visitation to national parks in the United States: Tests of the marginality, discrimination, and subculture hypotheses with national-level survey data. J. Outdoor Recreat. Tour. 7-8, 35-43. https://doi.org/10.1016/j.jort.2014.09.008

Landers, D.H., Simonich, S.M., Jaffe, D., Geiser, L., Campbell, D.H., Schwindt, A., Schreck, C., Kent, M., Hafner, W., Taylor, H.E., Hageman, K., Usenko, S., Ackerman, L., Schrlau, J., Rose, N., Blett, T., Erway, M.M., 2008. The Fate , Transport , and Ecological Impacts of Airborne Contaminants in Western National Parks (USA), EPA/600/R-07/138. U.S. Environmental Protection Agency, Office of Research and Development, NHEERL, Western Ecology Division, Corvallis, Oregon.

Landres, P., Meyer, S., Matthews, S., 2001. The Wilderness Act and Fish Stocking: An Overview of Legislation, Judicial Interpretation, and Agency Implementation. Ecosystems 4, 287-295. https://doi.org/10.1007/s10021

Larson, L.R., Whiting, J.W., Green, G.T., 2011. Exploring the influence of outdoor recreation participation on pro-environmental behaviour in a demographically diverse population. Local Environ. 16, 67-86. https://doi.org/10.1080/13549839.2010.548373

Lesnoff, M., Lancelot, R., 2012. aod: analysis of overdispersed data.

Likert, R., 1932. A technique for the Measurement of Attitudes. Arch. Psychol. 140, 1-55. Manfredo, M.J., 2008. Who Cares About Wildlife? Springer, New York, NY.

Manfredo, M.J., Dayer, A.A., 2004. Concepts for Exploring the Social Aspects of Human Wildlife Conflict in a Global Context 317-328. 
https://doi.org/10.1080/10871200490505765

Marion, J.L., Reid, S.E., 2009. Minimising Visitor Impacts to Protected Areas: The Efficacy of Low Impact Education Programmes. J. Sustain. Tour. 15, 5-27. https://doi.org/10.2167/jost593.0

Mccown, R.S., Laven, D., Manning, R., Mitchell, N., 2012. Engaging new and diverse audiences in the national parks: An exploratory study of current knowledge and learning needs. George Wright Forum 29, 272-284.

McFarlane, B.L., Boxall, P.C., 2000. Factors influencing forest values and attitudes of two stakeholder groups: The case of the foothills model forest, alberta, canada. Soc. Nat. Resour. https://doi.org/10.1080/08941920050121927

McKinley, D.C., Miller-Rushing, A.J., Ballard, H.L., Bonney, R., Brown, H., Cook-Patton, S.C., Evans, D.M., French, R.A., Parrish, J.K., Phillips, T.B., Ryan, S.F., Shanley, L.A., Shirk, J.L., Stepenuck, K.F., Weltzin, J.F., Wiggins, A., Boyle, O.D., Briggs, R.D., Chapin, S.F., Hewitt, D.A., Preuss, P.W., Soukup, M.A., 2017. Citizen science can improve conservation science, natural resource management, and environmental protection. Biol. Conserv. 208, 15-28. https://doi.org/10.1016/j.biocon.2016.05.015

Miller, Z.D., Freimund, W., Metcalf, E.C., Nickerson, N., 2017. Targeting your audience: wildlife value orientations and the relevance of messages about bear safety. Hum. Dimens. Wildl. 1209, 1-14. https://doi.org/10.1080/10871209.2017.1409371

Moran, P.W., Aluru, N., Black, R.W., Vijayan, M.M., 2007. Tissue contaminants and associated transcriptional response in trout liver from high elevation lakes of Washington. Environ. Sci. Technol. 41, 6591-7.

National Parks Omnibus Management Act of 1998, 1998. . USA.

National Parks Service, 2017. Annual Visitation Report by Years: 2007 to 2017 [WWW Document]. URL https://irma.nps.gov/Stats/SSRSReports/National Reports/Annual Visitation By Park (1979 - Last Calendar Year)

National Parks Service, 2007. Mountain Lakes Fishery Management Plan Environmental Impact Statement.

National Parks Service, 2006. National Parks Service Management Policies [WWW Document]. URL https://www.nps.gov/policy/MP_2006.pdf (accessed 3.19.18).

North Cascades National Park Service Complex Fish Stocking Act. H.R. 1158, 2014. . 113th Congress.

Obeng, E.A., Aguilar, F.X., 2018. Value orientation and payment for ecosystem services: Perceived detrimental consequences lead to willingness-to-pay for ecosystem services. J. Environ. Manage. 206, 458-471. https://doi.org/10.1016/j.jenvman.2017.10.059

Osbourne, J.W., Costello, A.B., 2009. Best Practices in exploratory factor analysis: Four recommendations for getting the most from your analysis. Pan-Pacific Manag. Rev. 12, 131-146. https://doi.org/10.1.1.110.9154

Papadimitriou, F., 2012. Modelling landscape complexity for land use management in Rio de Janeiro, Brazil. Land use policy 29, 855-861. https://doi.org/10.1016/j.landusepol.2012.01.004

Pergams, O.R.W., Zaradic, P. a, 2008. Evidence for a fundamental and pervasive shift away from nature-based recreation. Proc. Natl. Acad. Sci. 105, 2295-2300. https://doi.org/10.1073/pnas.0709893105 
Pister, E.P., 2001. Wilderness Fish Stocking: History and Perspective. Ecosystems 4, 279-286. https://doi.org/10.1007/s10021

R Core Team, 2016. R: A language and environment for statistical computing.

Raiche, G., 2010. nFactors: an R package for parallel analysis and non-graphical solutions to the Cattell scree test.

Revelle, W., 2017. psych: Procedures for Personality and Psychological Research.

Sarnelle, O., Knapp, R.A., 2004. Zooplankton recovery after fish removal : Limitations of the egg bank. Limnol. Oceanogr. 49, 1382-1392.

https://doi.org/https://doi.org/10.4319/lo.2004.49.4_part_2.1382

Schindler, D.W., Parker, B.R., 2002. Biological pollutants: alien fiches in mountain lakes. Water. Air. Soil Pollut. 2, 379-397.

Schoenfeld, C., Hendee, J.C., 1978. Wildlife management in wilderness. Boxwood Press.

Scott, D., Willits, F.K., 1994. Environmental Attitudes and Behavior: A Pennsylvania Survey. Environ. Behav. 26, 239-260.

Sharp, R.L., Larson, L.R., Green, G.T., 2011. Factors influencing public preferences for invasive alien species management. Biol. Conserv. 144, 2097-2104. https://doi.org/10.1016/j.biocon.2011.04.032

Steel, B.S., List, P., Shindler, B., 1994. Conflicting values about federal forests: A comparison of national and Oregon publics. Soc. Nat. Resour. 7, 137-153. https://doi.org/10.1080/08941929409380852

Taylor, P.A., Grandjean, B.D., Anatchkova, B., 2011. National Park Service comprehensive survey of the American public, 2008-2009: National Technical Report. Natural Resource Report NPS/NRPC/SSD/NRR-2011/295 295.

Teel, T.L., Manfredo, M.J., 2010. Understanding the Diversity of Public Interests in Wildlife Conservation. Conserv. Biol. 24, 128-139.

Teel, T.L., Manfredo, M.J., Jensen, F.S., Buijs, A.E., Fischer, A., Riepe, C., Arlinghaus, R., Jacbos, M.H., 2010. Understanding the Cognitive Basis for Human - Wildlife Relationships as a Key to Successful Protected-Area Management 40. https://doi.org/1.2753/IJS00207659400306

Tiberti, R., von Hardenberg, A., Bogliani, G., 2014. Ecological impact of introduced fish in high altitude lakes: A case of study from the European Alps. Hydrobiologia 724, 1-19. https://doi.org/10.1007/s10750-013-1696-1

U.S. Forest Service, 2016. National Visitor Use Monitoring Results National Summary Report. Ullrich, S.M., Tanton, T.W., Abdrashitova, S. a., 2001. Mercury in the aquatic environment: a review of factors affecting methylation. Crit. Rev. Environ. Sci. Technol. 31, 241-293. https://doi.org/10.1080/20016491089226

van der Linden, S., 2015. The social-psychological determinants of climate change risk perceptions: Towards a comprehensive model. J. Environ. Psychol. 41, 112-124. https://doi.org/10.1016/j.jenvp.2014.11.012

Vaske, J.J., Donnelly, M.P., 1999. A Value - Attitude - Behavior Model Predicting Wildland Preservation Voting Intentions. Soc. Nat. Resour. 12, 523-537. https://doi.org/10.1080/089419299279425

Venables, W., Ripley, B., 2015. MASS: Modern applied statistics with S. Fourth Edition. Vigliano, P.H., Beauchamp, D.A., Milano, D., Macchi, P.J., Alonso, M.F., Asorey, M.I.G., Denegri, 
M.A., Ciancio, J.E., Lippolt, G., Rechencq, M., Barriga, J.P., 2009. Quantifying Predation on Galaxiids and Other Native Organisms by Introduced Rainbow Trout in an Ultraoligotrophic Lake in Northern Patagonia, Argentina: A Bioenergetics Modeling Approach. Trans. Am.

Fish. Soc. 138, 1405-1419. https://doi.org/10.1577/T08-067.1

Washburne, R.F., 1978. Black Under-Participation in Wildland Recreation: Alternative Explanations. Leis. Sci. 1, 175-189.

Watson, A., Martin, S., Christensen, N., Fauth, G., Williams, D., 2015. The Relationship Between Perceptions of Wilderness Character and Attitudes Toward Management Intervention to Adapt Biophysical Resources to a Changing Climate and Nature Restoration at Sequoia and Kings Canyon National Parks. Environ. Manage. 56, 653-663. https://doi.org/10.1007/s00267-015-0519-8

Whittaker, D., Vaske, J.J., Manfredo, M.J., 2006. Specificity and the cognitive hierarchy: Value orientations and the acceptability of urban wildlife management actions. Soc. Nat. Resour. 19, 515-530. https://doi.org/10.1080/08941920600663912

Williams, C.K., Ericsson, G., Heberlein, T.A., Williams, C.K., Ericsson, G., Heberlein, T.A., 2016. A Quantitative Summary of Attitudes toward Wolves and Their Reintroduction (1972-2000). Wildl. Soc. Bull. 30, 575-584. 


\section{Supplementary Material}

\section{Supplementary Material 1}

Questionnaire (attached separately) 


\section{Supplementary Material 2}

Scree plots for exploratory factor analysis

Fig. SM1 Scree plot for group of responses to: "How would you rate your knowledge of..." Parallel analysis suggested using three factors. Based on the scree plot and eigenvalues, we selected to use one.

\section{scree plot}

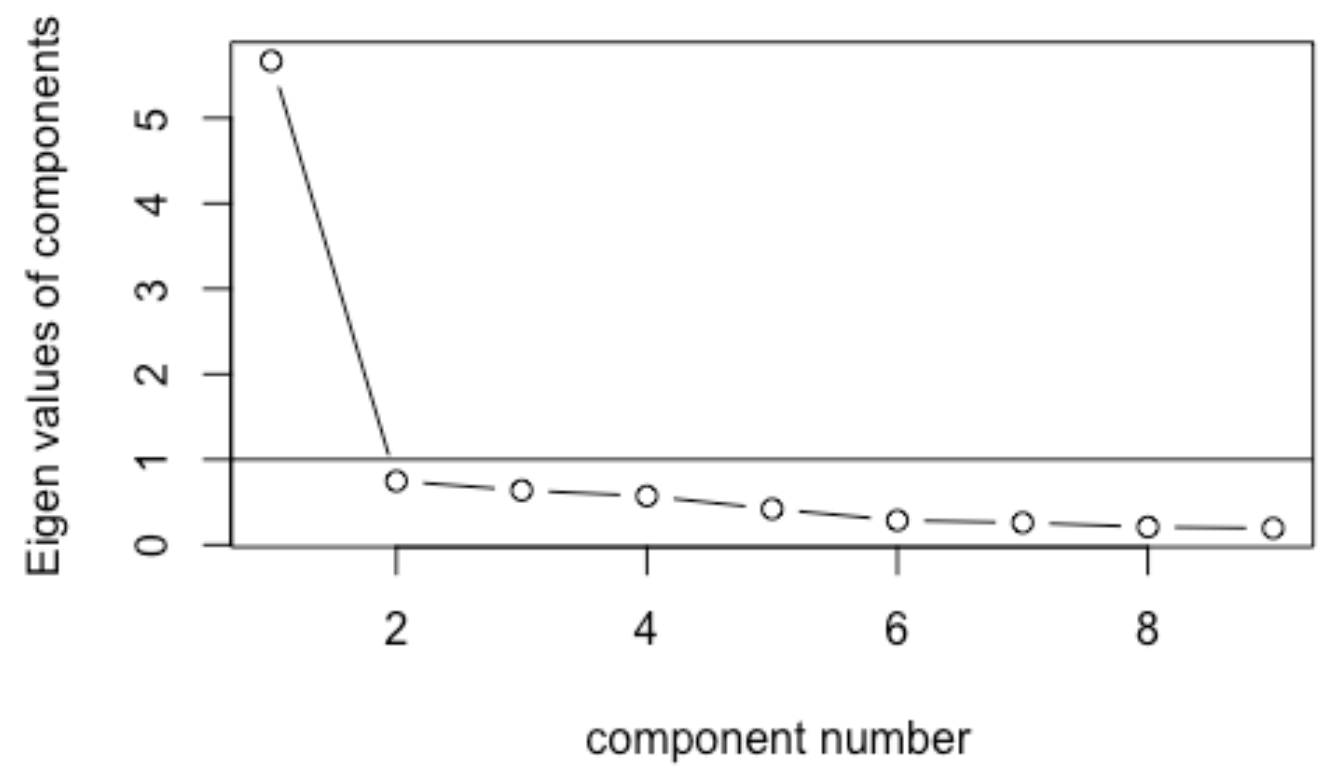


Fig. SM2 Scree plot for group of responses to: "National park lakes and streams are important for..." Parallel analysis suggested using three factors. We selected to use three factors, as all eigenvalues were $>1$ and percent variance explained by each factors was $>5 \%$.

\section{scree plot}

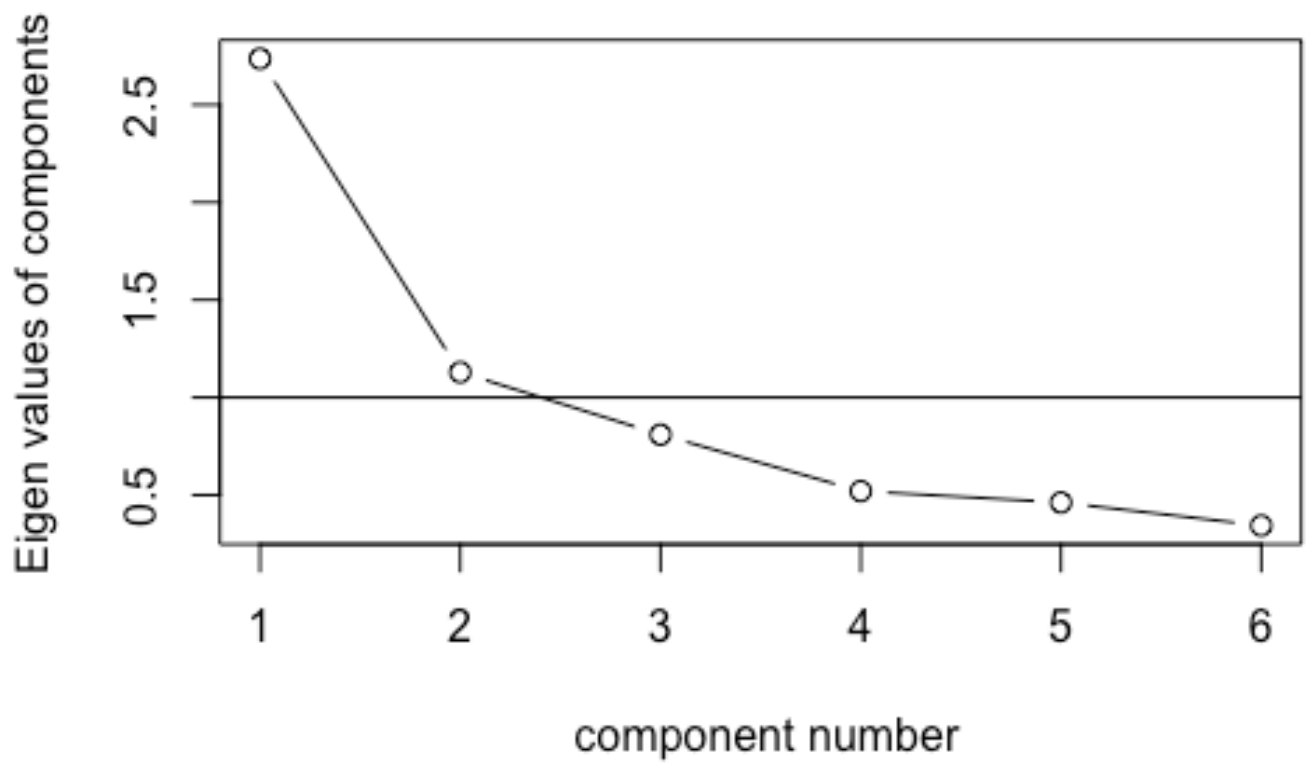


Fig. SM3 Scree plot for group of responses to mountain lake fisheries management attitude statements. Parallel analysis suggested using four factors. We selected to use four factors, as all eigenvalues were $>1$ and percent variance explained by each factors was $>5 \%$.

\section{scree plot}

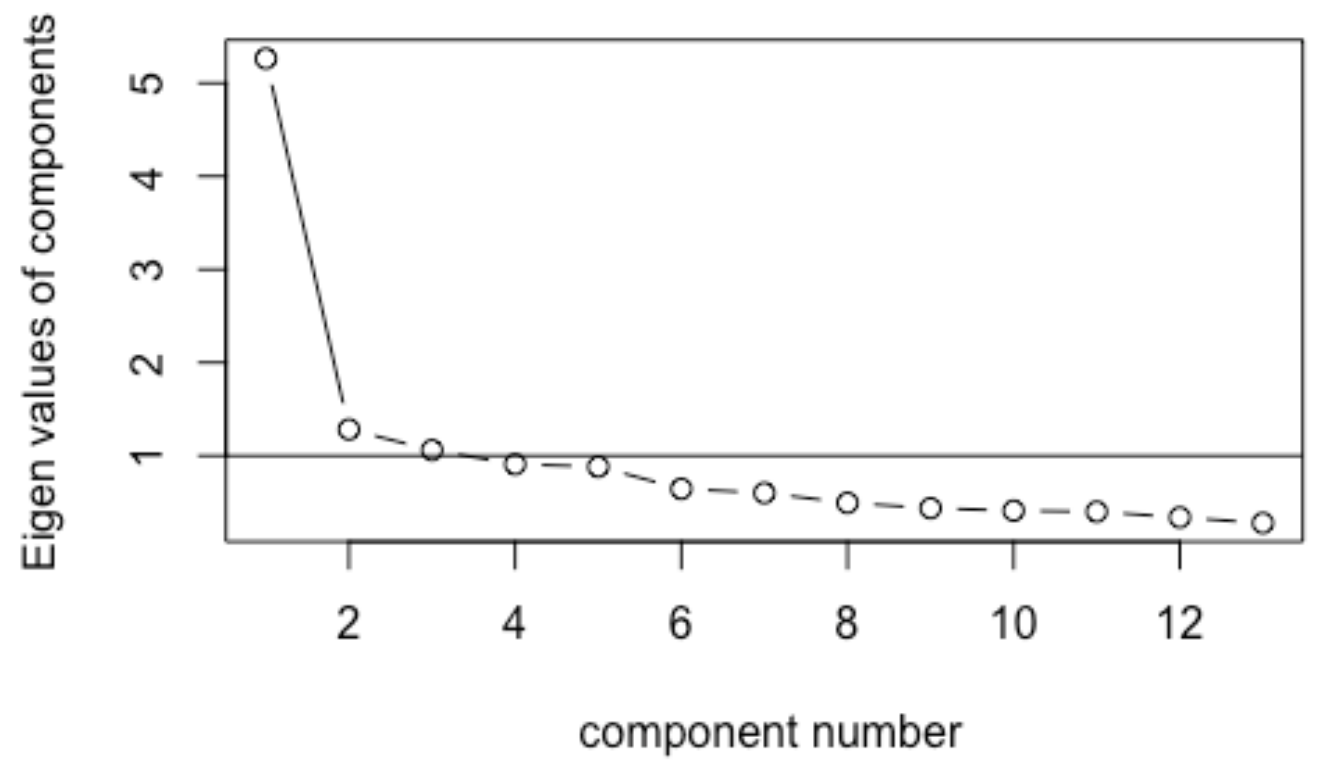




\section{Supplementary Material 3}

Exploratory factor analysis results for knowledge composite variable

Table SM1 Factor and factor loadings from exploratory factor analysis for selfranked knowledge of park ecosystems.

\begin{tabular}{l|c}
\hline $\begin{array}{l}\text { "Rank your knowledge } \\
\text { of..." }\end{array}$ & $\begin{array}{c}\text { Ecological knowledge } \\
\text { Factor } 1\end{array}$ \\
\hline Mammals and birds & 0.81 \\
Forests and alpine plants & 0.87 \\
Streams and lakes & 0.86 \\
Geologic formations & 0.75 \\
Park management & 0.56 \\
Aquatic animals & 0.70 \\
Glaciers & 0.77 \\
Biodiversity & 0.81 \\
Nutrient cycling & 0.70 \\
\hline Eigenvalue & 5.28 \\
Percent Variance & 0.59 \\
Explained & 0.93 \\
Cronbach's $\alpha$ & 1.87 \\
Mean index score &
\end{tabular}




\section{Portland State University \\ National Park Ecology Survey}

We are interested in learning about what motivates you to recreate in the national park, your knowledge about park ecosystems, and your values and beliefs regarding mountain ecosystems and recreational fishing. We think this information is important to help with communication of conservation information and to strengthen management programs focused on the health of mountain ecosystems; specifically, mountain lakes. Please feel free to ask any questions you have while taking this survey.

\section{Part 1}

Demographic information

Zip/postal code of current residence:

Country of residence:

Year born:

Gender (circle one): $\quad$ Male $\quad$ Female Prefer not to answer/other

Race/ethnicity (select all that apply):

Caucasian/white

Hispanic/Latino

African American/black

Native American or American Indian
Asian/Pacific Islander

Other:

Prefer not to answer

Level of education:

Some high school

High school diploma/ GED
Some college

Bachelor's degree
Master's degree

Doctorate degree

Personal income bracket:

$<\$ 25,000$

$\$ 25,000$ - $\$ 49,999$

$\$ 50,000-\$ 74,999$
$\$ 75,000$ - $\$ 99,999$

$\$ 100,000-\$ 149,999$

$\$ 150,000$ or higher
Prefer not to answer

\section{Flip page for Part 2}




\section{Part 2}

1. Are any of these activities the reason for your visit?

Check yes or no

- Overnight trip

- Day trip

- Hiking

- Sight-seeing/ scenic drives

- Camping

- Backpacking
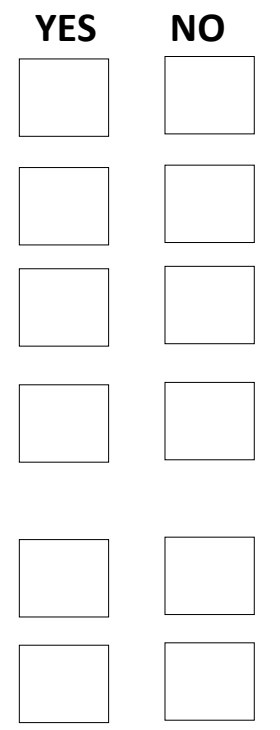
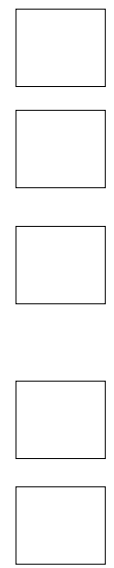

- Swimming

- Fishing

- Photography and/or art

- Picnicking

- Cycling

- Climbing

- Other:
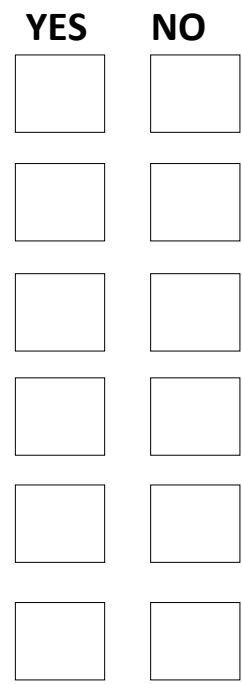

2. How would you rate your knowledge regarding the following aspects of park ecology?

- Mammals and birds

Very little knowledge

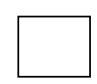

- Forests and alpine plants

- Streams and lakes

- Geologic formations

- Park management policies

- Aquatic animals (fish, amphibians, invertebrates)

- Glaciers

- Biodiversity

- Nutrient cycling

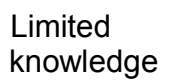

Average knowledge
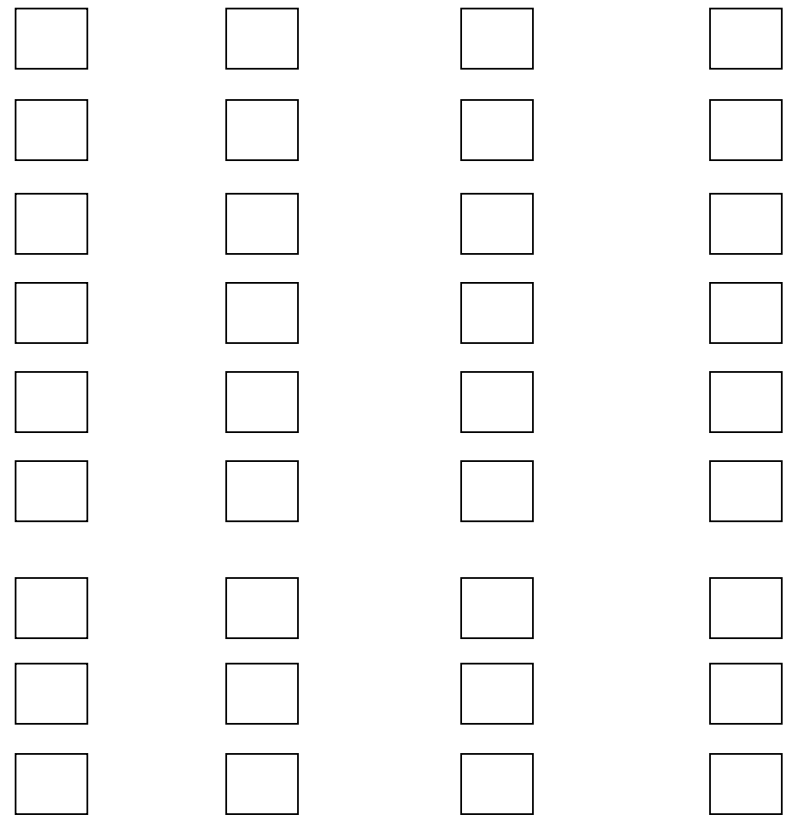

Very
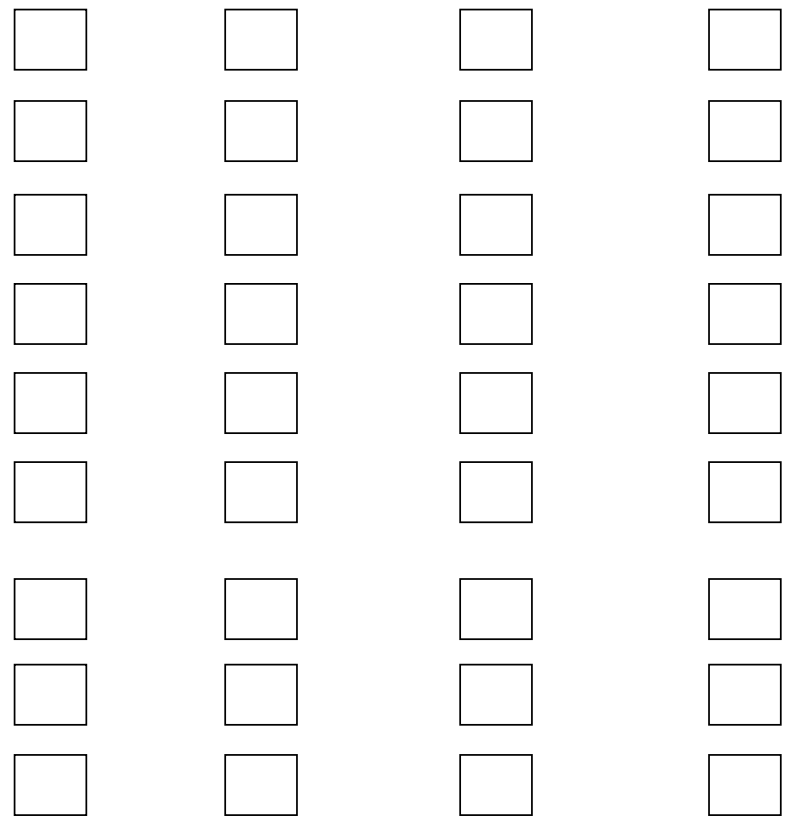
knowledgeable 
3. National Park lakes and streams are important for. . .

- Recreation

- Clean water

- Preserving biodiversity

- Fishing

- Intrinsic/existence value

- Culture

4. The National Park's ecosystems are healthy
Strongly agree

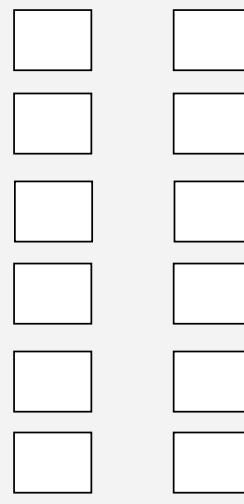

Agree
Neutral
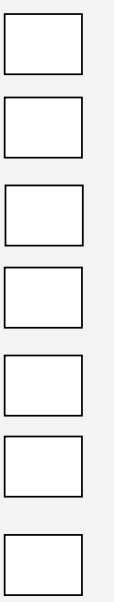
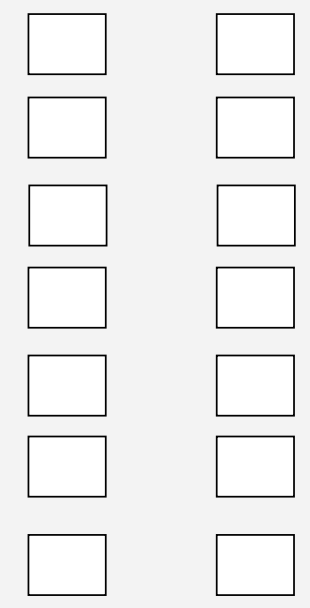

Strongly disagree

Don't know/ No opinion

5. Do you feel the following are threats to the health of the park's ecosystems?

- Climate change

- Biodiversity loss

- Air pollution

- Water pollution

- Visitor use

- Non-native/introduced species

- Resource extraction/harvesting

6. Rate the urgency of addressing the above threats:

- Climate change

- Biodiversity loss

- Air pollution

- Water pollution

- Visitor use

- Non-native/introduced species

- Resource extraction/harvesting
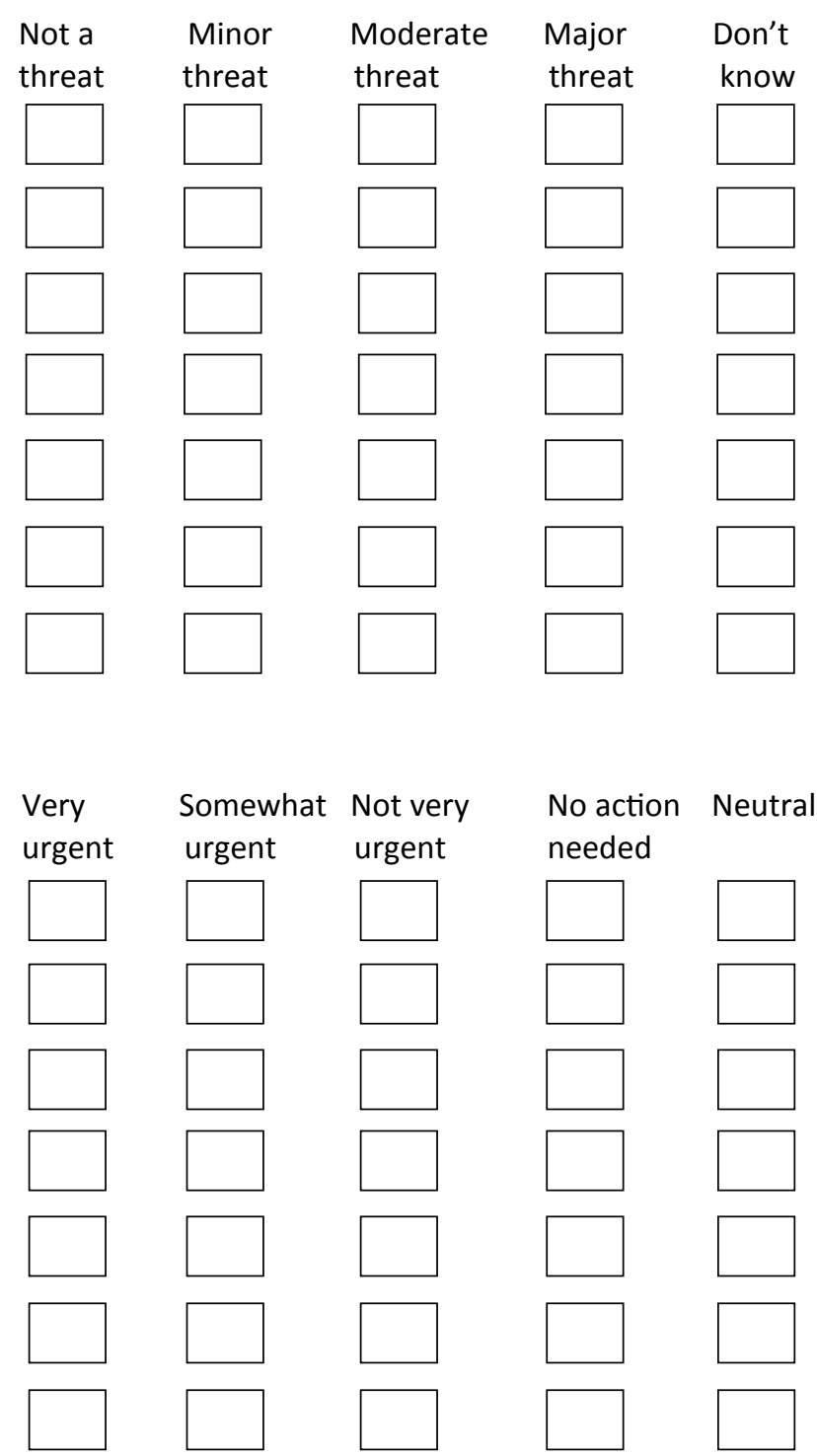

(C) 2018. This manuscript version is made available under the CC-BY-NC-ND 4.0 license http://creativecommons.org/licenses/by-nc-nd/4.0/ 
7. Did you know that the mountain lakes in the National Park did not historically have fish in them, but have been stocked with various trout species?

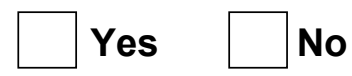

8. How much do you agree or disagree with each statement?

Stocking mountain lakes in the park with fish...

$\begin{array}{llll}\begin{array}{l}\text { Strongly } \\ \text { agree }\end{array} & \text { Agree } \quad \text { Neutral } & \text { Disagree } & \begin{array}{l}\text { Strongly } \\ \text { disagree }\end{array}\end{array}$

- is important for recreation

- adds value to the lakes

- $\quad$ benefits the other species in the lakes

- doesn't have any effect on the lake ecosystem

- has a negative effect on other species in the lake
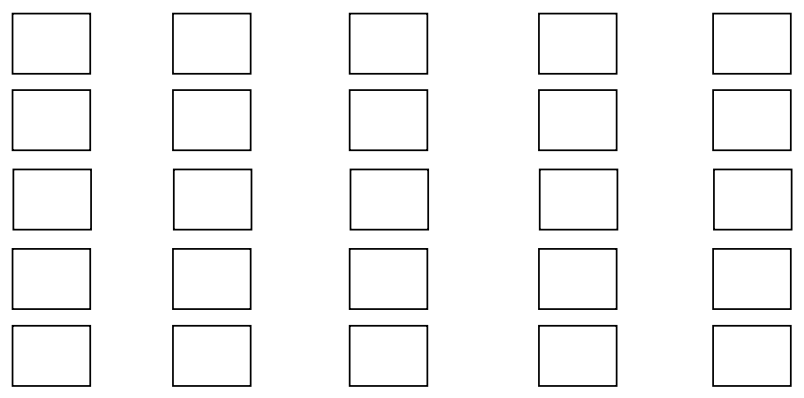

9. Do you ever read educational displays in visitor centers or on signs throughout the park?

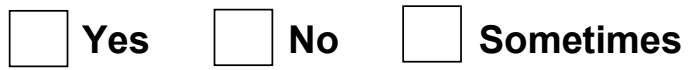

10. Are you a member of, or actively involved with, any environmental, recreational, or natural resourcefocused groups? List any you think apply.

Some examples include:

Mazamas, Hi-Lakers, North Cascades Institute, Washington Wild, Sierra Club, Trout Unlimited.

11. Have you ever fished in this park, or in other National Parks or public lands (e.g. National Forest )?

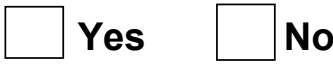

If no, is this an activity that you have interest in for future visits?

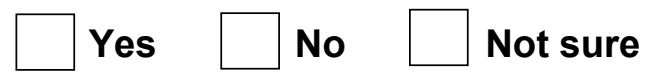

12. Would you consider the fish from this National Park to be safer to eat than one (of the same species):

- Purchased at a grocery store?

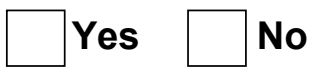

Not sure

- Caught from a lowland water
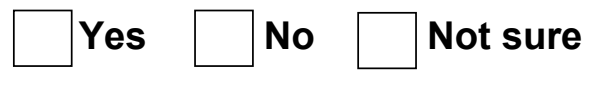
body?

- From the ocean?
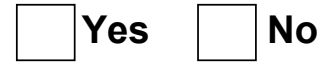

Not sure 
Please read the following statement and then answer the questions below:

Mountain lakes were historically fishless. Stocking of mountain lakes began at the turn of the $20^{\text {th }}$ century to encourage public support of conservation. Scientists at the park have begun to understand that stocking fish in mountain lakes can have a detrimental effect on the rest of the mountain lake ecosystem. Research has shown that fish can negatively impact the biodiversity of some of the lakes. Specifically, fish are associated with declines in amphibians (frogs and salamanders), invertebrate animals (insects and zooplankton), and even alpine birds. In response, the park has started to intentionally remove fish from some lakes using gill nets and a piscicide (fish killer) called rotenone, which is plantbased and quickly disintegrates after treatment, meaning it will not harm humans who visit the lake).

13. Please indicate how much you agree or disagree with each statement:

- The concerns regarding fish stocking are legitimate.

- Action should be taken to alleviate the effects of fish on all mountain lake ecosystems.

- Removing fish is an appropriate approach to restoring mountain lake ecosystems.

- The benefits of stocking fish outweigh the ecological consequences.

- Fish add value to all mountain lake ecosystems, despite any potential concerns.

- People are keep blowing environmental issues out of proportion and fish stocking is just another example.

- Stocking programs should be reinstated.

- Some lakes should be designated for fishing and some for pristine nature.

- Removing fish from some lakes will increase visitor pressure on lakes that still have fish.

- I think removing fish from the lakes may be just as harmful as keeping fish in the lakes.

- I think fish should be removed, but only using manual methods (gill nets, angling), as opposed to chemicals.

- I don't have an opinion about this.

- I still don't know enough about the issue to have an informed opinion

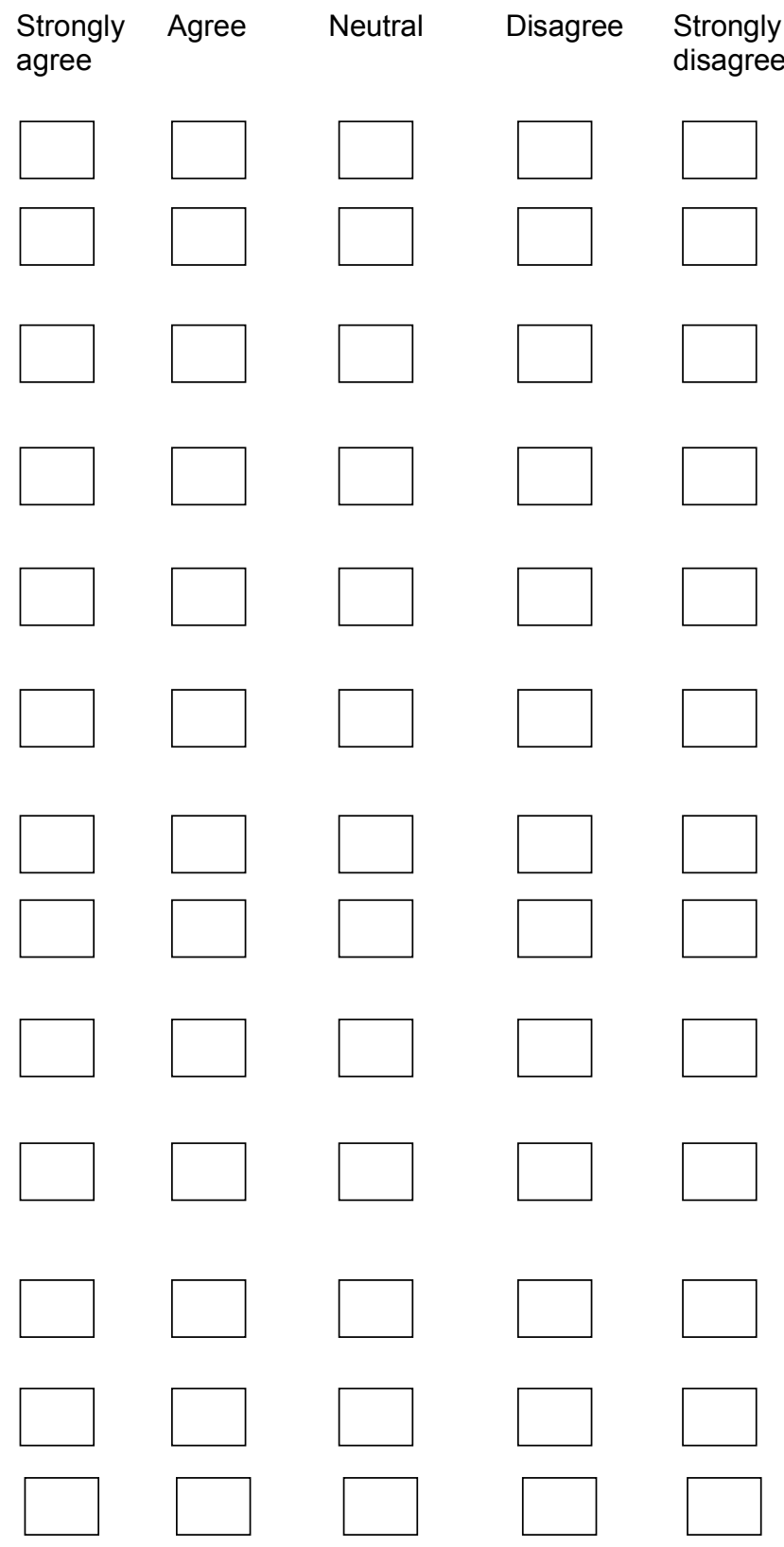

This marks the end of the survey for those who have never fished in National Parks or on other public lands. Please return this survey to the researcher. Otherwise, continue to the next page. 
If you have fished in this park, or on other public lands, please answer the following questions:

14. Have you fished in any of the following places in this park?

- Lowland reservoirs and lakes

- Streams/rivers

- Mountain lakes

(high elevation, usually accessed by trail)

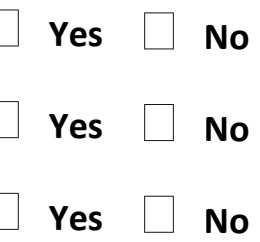

15. How often/how frequently have you visited the park for the purpose of fishing? Select one response.
Just once
$10+$ times
1-5 times
More than I can count
5-10 times
Don't know/don't remember

16. For how many years have you been fishing here, or at other National Parks or public lands?

About $\square$ years.

17. How important are the following when you consider where to fish?

- Lakes that are popular for fishing

- Lakes with high fish density/where I think I'll catch the most

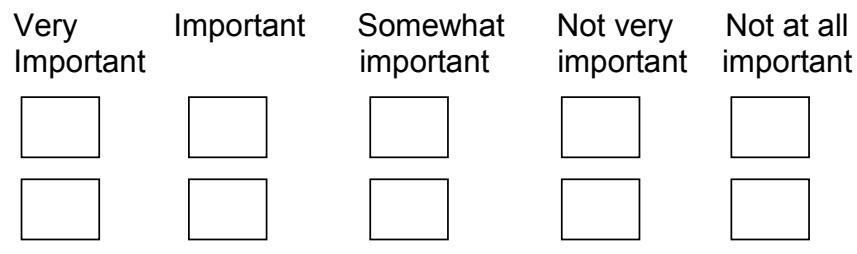

- Lakes that are easily accessed
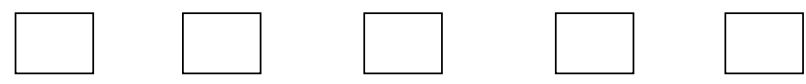

- Reservoirs/large lakes

- Lakes that are far away

- Lakes that are pristine

- Lakes with the least number of people

- Lakes that are most scenic/have the best view

- Other:
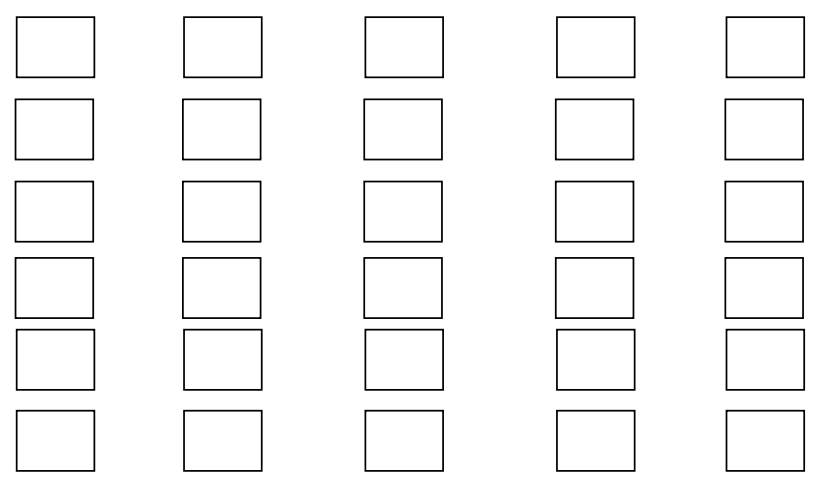

18. Have you ever consumed the fish you catch from mountain lakes in the National Park?

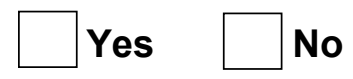

19. If so, on how many occasions do you consume fish each year, on average?

Just once

1-5 times
$5-10$

$>10$
Don't know/don't remember

Never

This marks the end of the survey, please return the survey to the researcher. 